\title{
The Application of Prussian Blue Nanoparticles in Tumor Diagnosis and Treatment
}

\author{
Xiaoran Gao ${ }^{\dagger}$, Qiaowen Wang ${ }^{\dagger}$, Cui Cheng * ${ }^{\mathbb{D}}$, Shujin Lin, Ting Lin, Chun Liu and Xiao Han \\ College of Biological Science and Engineering, Fuzhou University, Fuzhou 350108, China; \\ N185720009@fzu.edu.cn (X.G.); wendyeveryday@163.com (Q.W.); linshujin32@163.com (S.L.); \\ lintingtt33@163.com (T.L.); ibptlc@fzu.edu.cn (C.L.); hanxiao@fzu.edu.cn (X.H.) \\ * Correspondence: ibptcc@fzu.edu.cn; Tel.: +86-0591-83725260 \\ t These authors contributed equally to this work.
}

Received: 5 November 2020; Accepted: 30 November 2020; Published: 3 December 2020

\begin{abstract}
Prussian blue nanoparticles (PBNPs) have attracted increasing research interest in immunosensors, bioimaging, drug delivery, and application as therapeutic agents due to their large internal pore volume, tunable size, easy synthesis and surface modification, good thermal stability, and favorable biocompatibility. This review first outlines the effect of tumor markers using PBNPs-based immunosensors which have a sandwich-type architecture and competitive-type structure. Metal ion doped PBNPs which were used as $\mathrm{T}_{1}$-weight magnetic resonance and photoacoustic imaging agents to improve image quality and surface modified PBNPs which were used as drug carriers to decrease side effects via passive or active targeting to tumor sites are also summarized. Moreover, the PBNPs with high photothermal efficiency and excellent catalase-like activity were promising for photothermal therapy and $\mathrm{O}_{2}$ self-supplied photodynamic therapy of tumors. Hence, PBNPs-based multimodal imaging-guided combinational tumor therapies (such as chemo, photothermal, and photodynamic therapies) were finally reviewed. This review aims to inspire broad interest in the rational design and application of PBNPs for detecting and treating tumors in clinical research.
\end{abstract}

Keywords: Prussian blue nanoparticles; immunosensors; imaging; drug delivery; imaging-guided therapy

\section{Introduction}

To date, cancer is still one of the most prevalent and deadliest diseases globally, with more than 200 different types of cancer that can result in more than 60 organ dysfunctions [1]. Increased mortality rates are mainly associated with the metastasis of solid tumors produced by large masses of tissue in the majority of cancer-related cases. In general, the limitation of early tumor diagnosis makes it less likely that tumors can be detected in the optimal treatment window. Once the most treatable stage passes, the tumor is likely to spread uncontrolled through the body by damaging the majority of healthy tissue, and this often leads to death [2,3]. In view of these issues, developing diagnostic techniques can be helpful for the early detection of tumor metastasis and their timely treatment using therapeutic agents that provide new possibilities for the efficient treatment of tumors.

Importantly, the level of tumor markers in human serum is much higher for patients with certain types of tumors. This can be a specific indication of the presence of tumors for early identification in clinical applications [4,5]. In the early stages of the disease, only trace amounts of biomarkers exist in body fluids. Hence, the development of sensitive and accurate detection techniques is of importance. Electrochemical immunosensors have been rapidly developed as alternatives to traditional immunoassay methods for determination of tumor markers; this has been achieved by combining the specific interactions between the antigen and antibodies with a convenient device structure. Due to 
their high specificity, miniaturization, low cost, real-time detection automation, and the capacity for multi-target analyses compared with traditional immunoassay methods, the resulting device can meet the requirements of point-of-care testing (POCT) and provide sensitive and convenient molecular diagnosis for underserved populations or community health-care systems [6-8]. Prussian blue (PB) is an iron centered compound $\left(\mathrm{Fe}_{4}\left[\mathrm{Fe}(\mathrm{CN})_{6}\right]_{3} \cdot \times \mathrm{H}_{2} \mathrm{O}\right.$, where iron atoms have different oxidation states $\left(\mathrm{Fe}^{2+} / \mathrm{Fe}^{3+}\right)$ and $\mathrm{x}$ is the number of water molecules) and is one of the oldest coordination compounds reported in the literature $[9,10]$. Since the accidental discovery of PB in 1704 by Diesbach, it took 274 years for its application as an electroactive film [11,12]. The development of PB was reported by Chu [13] in detail. Interstitial modifications and substitution of $\mathrm{PB}$ can generate a series of new coordination compounds, which are referred to as PB analogs (PBAs) [14]. PB and PBA, as a peroxidase analog, can provide a sensitive electrochemical response by catalyzing the reduction of hydrogen peroxide $\left(\mathrm{H}_{2} \mathrm{O}_{2}\right)$ at lower dosages and supporting the integration of the oxidase enzymes while decreasing other electrochemical interferents [15-17]. A tuned core-shell, hollow, or substrate-supported PB/PBA framework enables electrolyte diffusion to enhance electrochemical performances [18]. Furthermore, the application of different nanomaterials such as graphene, carbon nanotubes, quantum dots, magnetic particles, and gold nanoparticles deposited on PB/PBA offer new avenues to increase the sensitivity $[19,20]$. In previous studies, PB/PBA-based biosensors were considered to be one of the most efficient electron-transfer mediators for applications including the determination of tumor markers, antihypertensive drugs, glucose, lactate, ascorbic acid, DNA, ions, and pH [21-28]. Thus, several strategies for signal amplification have been used to enhance the electrochemical response. Furthermore, strategies such as the application of different nanomaterials have been applied to improve the sensitivity, which is highly desired for detecting ultra-low amounts of target tumor markers.

With the continued development of nanoscience and nanotechnology, theranostics nanoplatforms have also been engineered for precision treatment of tumors by combining therapy with suitable imaging modality. This can be used to evaluate and optimize the therapeutic effect in real time via visual monitoring of the therapeutic procedure $[29,30]$. PB nanoparticles (PBNPs) have been reported in numerous applications, including for early tumor diagnostics via medical imaging such as $\mathrm{T}_{1}$-weight magnetic resonance imaging (MRI), photoacoustic imaging (PAI), and multi-model imaging [31]. It is reported that PBNPs were demonstrated as an effective $\mathrm{T}_{1}$-weighted cellular MRI contrast agent in 2010 [32], but it is approximately an order of magnitude lower than clinical $\mathrm{T}_{1}$-weighted MRICAs due to their poor ordinary longitudinal relaxivity. So, promoted their diagnostic capability by achieving a larger $r_{1}$ with a smaller amount of injected PBNPs metallic ions has become a topic of intense research interest in recent years [33-38]. The PBNPs with a blue appearance can cause transient thermoelastic expansion via strong NIR absorption and provide ultrasonic signals for PAI [39], and modified PBNPs have better photothermal stability and photoacoustic signal-to-noise ratio [40]. PAI technique via PBNPs as a CA to label tumor or lable mesenchymal stem cells has been broadly exploited for noninvasive imaging and timely monitoring the recovery process [41-43], because it has high spatial resolution, strong contrast, noninvasiveness, real-time imaging, low cost, and the ability for both endogenous and exogenous imaging [44]. Hollow or mesoporous PBNPs have been usefully employed as nanocarriers to deliver theranostic agents because of their large intrinsic internal pore volume, tunable size, and simple synthesis [45]. Additionally, surface modification enables the PBNPs to effectively accumulate drugs at tumor sites via passive or active targeting, which overcomes the weaknesses of conventional drugs, including systemic toxicity, short circulation time, inefficient target specificity, and poor solubility [46,47]. In addition, PBNPs, which are an excellent candidate for photothermal therapy (PTT), have high optical absorption properties in the NIR region between 650-900 nm because of intervalence charge transfer between $\mathrm{Fe}^{2+}$ and $\mathrm{Fe}^{3+}$ in PB. This enables tumor eradication via cytotoxic heat generated from the PBNPs $[48,49]$. PBNPs can catalyze $\mathrm{H}_{2} \mathrm{O}_{2}$ into $\mathrm{O}_{2}$ in the existence of $\mathrm{H}_{2} \mathrm{O}_{2}$ to realize $\mathrm{O}_{2}$ self-supplied mode within solid tumors, and then improve the hypoxia of tumors and provide conditions for photodynamic therapy (PDT). It can also control the $\mathrm{H}_{2} \mathrm{O}_{2}$ decomposition rate via local temperature variation of PBNPs under 
NIR laser irradiation [50]. More importantly, several reports demonstrated that PBNPs have good biocompatibility and nontoxicity because of the tight bond between the cyano groups and iron [51,52]. Therefore, PBNPs-based composites might serve as a promising theranostics nanoplatform and overcome limitations such as a lack of accuracy, sensitivity, and real-time diagnosis. Additionally, therapy limitations such as resistance, inefficiency, and control in the biomedical field could potentially be overcome.

In this review, we briefly discuss recent advancements in the biomedical field involving the properties of PB-based nanoobjects as electron-transfer mediators for immunosensing, nanoprobes for imaging, therapeutic agents, and as nanocarriers for drug delivery (Figure 1). The application of PBNPs in the biomedical field in multimodal diagnostic techniques (biosensing or imaging) and therapy (chemo, PTT, PDT) of tumors have been summarized. In addition, in the tumor theranostic section, we mainly focused on multimodal imaging-guidance using combinational strategies for tumor therapy rather than individual ones. This review hopes to inspire broader consideration for the rational design of systems for the detection and treatment of tumors in clinical research.

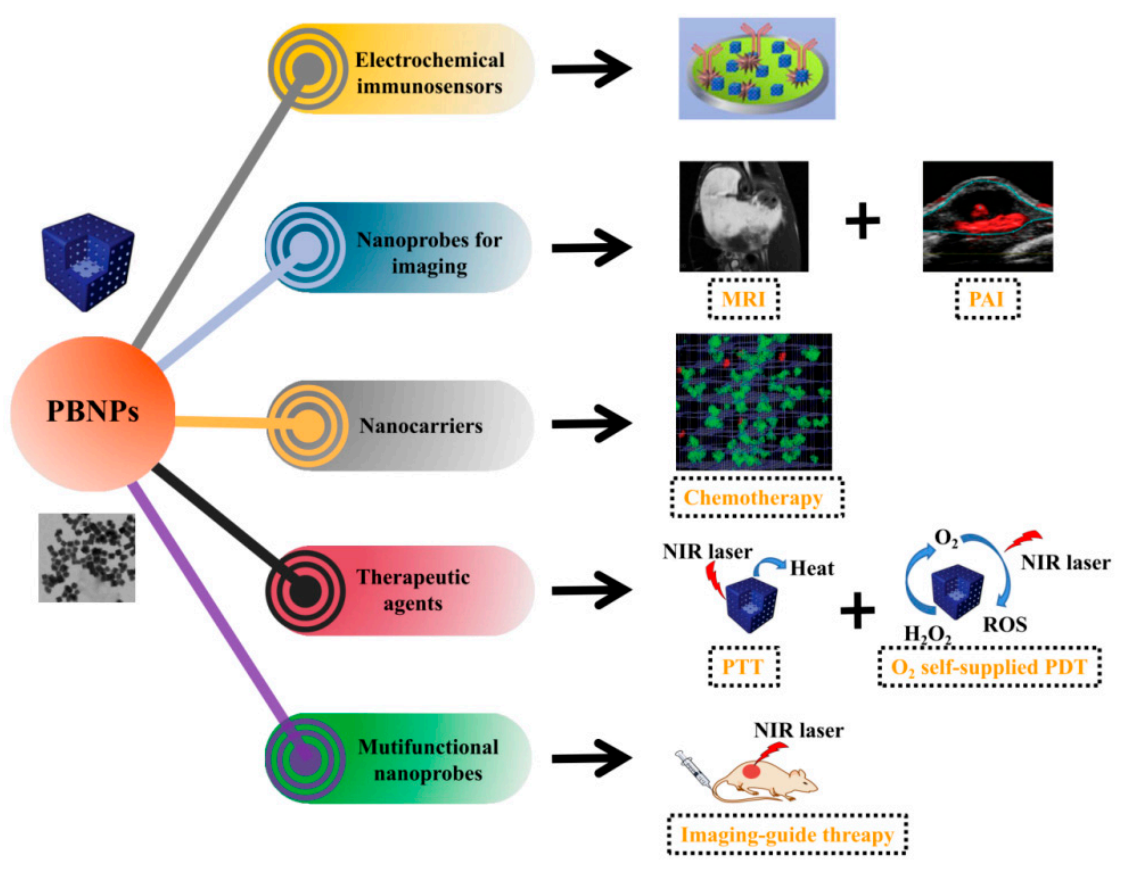

Figure 1. The schematic illustration of PBNPs in the applications of tumor diagnosis and therapies.

\section{PBNPs for Tumor Diagnosis in Electrochemical Immunosensors}

For the screening and diagnosis of tumors, intensive research has gone into choosing specific and sensitive methods to improve the determination of tumor markers. The concentration of these biomarkers can be used to determine the stages of the tumor [53,54]. The enzyme-linkedimmunosorbent assay (ELISA) is a conventional commercially available test for clinical diagnoses. However, some restrictions exist related to the relatively weak sensitivity, the detection levels of the protein in the advanced disease stage, long analysis time, high costs, and difficulty in application in the absence of a classical diagnostic laboratory. Electrochemical immunosensors, as a type of biosensor, monitor the content of analytes in a sample via recognition between the antibody and antigen (target analyte), and it has attracted increasing interest in tumor diagnosis because of its low instrumentation cost, simplicity, compactness, and automated testing capabilities [55]. Electrochemically depositing PB layers onto platinum was first reported by Neff in 1978 [11]. A few years later, Itaya et al. developed a versatile method for the deposition of a thin layer of PB on different electrode materials $\left(\mathrm{SnO}_{2}\right.$, glassy carbon, gold, platinum) and demonstrated high stability after 105 cycles $[56,57]$. They also reported that $\mathrm{PB}$ had the capability to reduce $\mathrm{O}_{2}$ and $\mathrm{H}_{2} \mathrm{O}_{2}$ in the 
reduced form and oxidize $\mathrm{H}_{2} \mathrm{O}_{2}$ in the oxidized form; additionally, it could function as an electron transfer mediator because of the generation of two-electron transfer channels via the redox reactions in $\mathrm{PB}$ (high-spin $\mathrm{Fe}^{3+/ 2+}$ and low-spin $\left[\mathrm{Fe}(\mathrm{CN})_{6}\right]^{3-/ 4-}$ ). The peculiar structure of $\mathrm{PB}$ allowed the diffusion of $\mathrm{O}_{2}$ and $\mathrm{H}_{2} \mathrm{O}_{2}$ through the crystal [58]. Then, Karyakin et al. reported a first-generation amperometric glucose biosensor that used $\mathrm{PB}$ as an electrocatalyst for $\mathrm{H}_{2} \mathrm{O}_{2}$ in 1994 [59]. Therefore, $\mathrm{PB}$, as a typical electron transfer mediator and $\mathrm{H}_{2} \mathrm{O}_{2}$ catalyst, has been widely used in electrochemical biosensors $[15,60]$.

In particular, we focus on electrochemical immunosensors for the detection of multiplex tumor biomarkers in human serum (e.g., carcinoembryonic antigen (CEA), alpha-fetoprotein (AFP), carcinoma antigen 125 (CA125), cancer antigen 15-3 (CA 15-3), apolipoprotein A1 (ApoA1), and cytokines) based on the use of PB deposited on graphene, carbon nanotubes, quantum dots, magnetic particles, and gold nanoparticles as novel strategies for improved early tumor diagnostics. Generally, the most popular types of immunosensors are the sandwich and competitive types. (Figure 2) For the sandwich type, the analyte is first captured by the corresponding antibody and is then detected using another labeled antibody [8]. Dai et al. reported that PB modified hydroxyapatite was used as a carrier of the tracer (horse radish peroxidase (HRP)) and secondary anti-AFP antibodies $\left(\mathrm{Ab}_{2}\right)$, and thionine (TH), and graphene sheets (GS) were used to capture the anti-AFP antibody $\left(\mathrm{Ab}_{1}\right)$. This concept showed an increase in the value of current with increasing AFP concentration in the range of 0.02 to $8 \mathrm{ng} / \mathrm{mL}$, with a limit of detection (LODs) of $9 \mathrm{pg} / \mathrm{mL}$ [61]. Generally, the average concentration of AFP in healthy adults is as low as $3.4 \mathrm{ng} / \mathrm{mL}$ [62]. This immunosensor prepared by Dai et al. has the advantages of high sensitivity and selectivity, and has been used applied to the analysis of AFP with satisfactory results. An increased concentration of tumor necrosis factor- $\alpha$ (TNF- $\alpha$ ) was also associated with the tumor, while the amount of TNF- $\alpha$ in the human body was very low $(10-30 \mathrm{pg} / \mathrm{mL})$ [63]. It has been reported that PB modified ceria nanoparticles were used as an electrochemical label for the detection of TNF- $\alpha$ because of its high sensitivity for $\mathrm{H}_{2} \mathrm{O}_{2}$ detection. The proposed sandwich-format immunosensor had a wide linear range $(0.005-5 \mathrm{ng} / \mathrm{mL})$ and a LOD of $2 \mathrm{pg} / \mathrm{mL}$ for TNF- $\alpha$, which exceeded the LODs of the ELISA technique in the human body (Figure 2a) [21]. So, it is important to investigate the structural design of different nanoparticle-based catalysts, which has been used as new supporting matrix for PBNPs, to enhance the catalytic activity and obtain synergistic effect. Nevertheless, most tumors have more than a single marker associated with their presence. Simultaneous determination of multiple biomarkers can enhance the diagnostic specificity between the biomarkers and tumor [64,65]. Lai et al. designed a screen-printed carbon electrode arrays (SPCEs) for ultrasensitive multiplexed measurement of tumor markers using PB as a mediator to catalyze the $\mathrm{H}_{2} \mathrm{O}_{2}$ produced by HRP with CEA and AFP as analytes. The LODs of AFP and CEA were 1.4 and $2.2 \mathrm{pg} / \mathrm{mL}$, respectively [66]. HRP immobilized on PBNPs was a good method to enhance the enzymatically catalytical signal, and it could eliminate the electrochemical cross talk by the use of electrode arrays and single-enzyme label. However, the HRP label is environmentally unstable, requiring a nitrogen atmosphere and deoxygenation process, and the electrode arrays are not reusable resulting in a high-cost system $[67,68]$. Chen et al. simultaneously obtained LODs of $0.05 \mathrm{ng} / \mathrm{mL}$ for AFP and $0.1 \mathrm{ng} / \mathrm{mL}$ for CEA using a sandwich-type immunosensor without enzymatic reaction, which fully satisfied the requirements for clinical diagnosis with threshold values of $10 \mathrm{ng} / \mathrm{mL}^{-1}$ for AFP and of $3 \mathrm{ng} / \mathrm{mL}^{-1}$ for CEA in normal human serum; though, the LOD values were lower than for other studies with enzymatic reactions [69]. Therefore, if different antibodies were immobilized on the electrode at the same time, the low detection limit was got without enzymatic reaction. It could also help to avoid the use of the throwaway electrode arrays, which made the detection cheaper. 
(a)
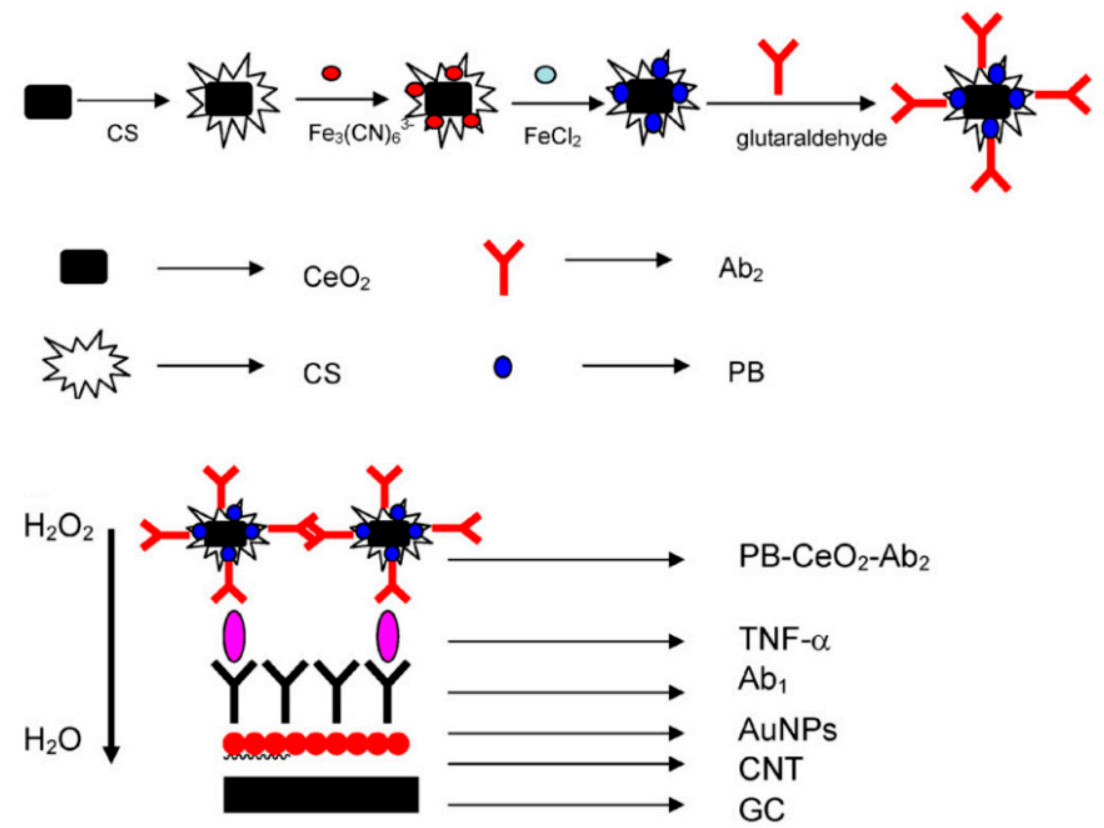

(b)

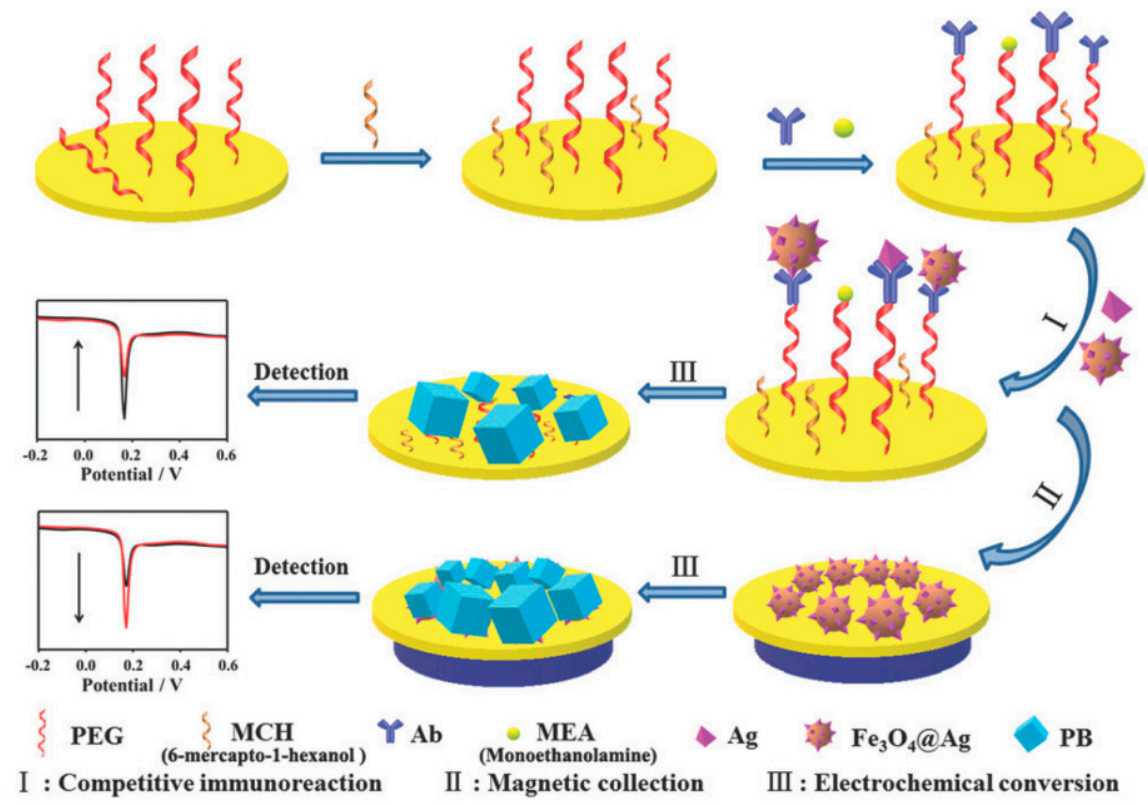

Figure 2. Schematic illustration of the electrochemical immunosensor fabrication process for sandwich format (a) and competitive format (b), adapted with permission from ref. [21,70].

Another immunosensor format is the competitive type. Here, the signal of the antigen in a sample can be detected from the labeled antigen via competition between the labeled antigen and antigen in the sample, which reacts with the immobilized antibody. The detected electrochemical signal decreases with increasing analyte concentration $[8,71,72]$. Li et al. developed a competition-format immunosensor with low fouling for CA 15-3 detection using PEG as an antifouling polymer to decrease the adsorption of the nonspecific protein. Moreover, they considered $\mathrm{Fe}_{3} \mathrm{O}_{4}$ nanoparticles could release $\mathrm{Fe}^{3+}$, which triggered the growth of $\mathrm{PB}$ on the sensing interface and further generated and amplified the signals detected by the immunosensors [73]. Pure CA 15-3 and CA 15-3 functionalized $\mathrm{Fe}_{3} \mathrm{O}_{4}\left(\mathrm{Fe}_{3} \mathrm{O}_{4} @ \mathrm{Ag}\right)$ were thus used to competitively bind to the immobilized CA 15-3 antibody. Then, the signals for sensing were generated by $\mathrm{PB}$ due to electrochemical conversion of $\mathrm{Fe}_{3} \mathrm{O}_{4}$. The results showed that the amount of $\mathrm{Fe}_{3} \mathrm{O}_{4} @ \mathrm{Ag}$ bonded to the electrode surface decreased with increasing concentration of CA 15-3, which is because of the competitive immunoreaction that causes a reduction 
in the detectable signals. A linear relationship between the current and the logarithm of the CA 15-3 concentration was obtained in the range of 10 to $1000 \mu \mathrm{U} / \mathrm{mL}$, with a LOD of $5.2 \mu \mathrm{U} / \mathrm{mL}$ (Figure 2b) [70]. It is seen that the combination of the traditional electrode and a magnetic electrode could be a new strategy to generate and amplify the detecting signals for sensing. In general, compared with sandwich-type immunosensors, the competition-type immunosensor is less complex and has a lower incubation time, but it has a smaller linear range. Both types of immunosensor can be easily extended to detect various biomarkers.

The better clinical utility related to early detection has highlighted the need for sensitive tumor markers. The improved recognition of PB electrochemical behavior has been demonstrated, and it is expected that PBNPs-based immunosensors can be promising for screening, diagnosis, and prognosis of different tumors. This can lead to the sensitive and early detection of tumor markers for cancer prevention in high-risk individuals or to effectively eradicate tumors at an early point with a low tumor load.

\section{PBNPs for Tumor Diagnosis in Biological Imaging}

This section may be divided by subheadings. It should provide a concise and precise description of the experimental results, their interpretation as well as the experimental conclusions that can be drawn.

\subsection{Magnetic Resonance Imaging}

Magnetic resonance imaging (MRI) is a non-invasive imaging tool that has several advantages, including a high spatial resolution, high signal penetration depth, non-ionizing radiation, excellent soft tissue contrast, and wide clinical applicability. In practical clinical trials, CAs are used to further enhance the MRI sensitivity and obtain improved image quality by changing the relaxation time to increasing the relaxation rate around the agents. In general, MRI CAs are primarily $\mathrm{T}_{1}$-weighted agents with a positive image effect (bright spots) and $\mathrm{T}_{2}$-weighted agents with a negative image effect (dark spots) [16]. $\mathrm{T}_{1}$ contrast agents are conducive to bright spots because they increase the signal intensity in $T_{1}$-weighted images via a shortened $T_{1}$. $T_{2}$ contrast agents enable dark spots because the $\mathrm{T}_{2}$ contrast effect reduces the signal intensity in the $\mathrm{T}_{2}$-weighted images [74]. Because it is difficult to recognize the dark region from the background, the $T_{2}$-weighted imaging is not satisfactory [75]. In 2010, Shokouhimehr et al. first demonstrated that PBNPs with single-crystal-like feature were an effective $\mathrm{T}_{1}$-weighted cellular MRI contrast agent [32]. A PBNP is a mixed-valence iron hexacyanoferrate with the approximate formula $\mathrm{A}_{4 x} \mathrm{Fe}^{\mathrm{III}}{ }_{4}\left[\mathrm{Fe}^{\mathrm{II}}(\mathrm{CN})_{6}\right]_{3+\mathrm{x}} \cdot \mathrm{nH}_{2} \mathrm{O}\left(\mathrm{A}=\mathrm{Li}^{+}, \mathrm{Na}^{+}, \mathrm{K}^{+}, \mathrm{Rb}^{+}, \mathrm{Cs}^{+}, \mathrm{NH}^{4+}, \mathrm{Tl}^{+}\right.$; $0 \leq \mathrm{x} \leq 1, \mathrm{n}=14-16$; abbreviated as PBNPs). The $\mathrm{Fe}^{3+}$ centers with a high-spin $(\mathrm{S}=5 / 2)$ have the ability to coordinate with water protons, and thus offer relaxivity. However, PBNPs have a poor capacity for MRI diagnosis and ordinary longitudinal relaxivity, which is approximately an order of magnitude lower than clinical $\mathrm{T}_{1}$-weighted MRICAs [33]. Increasing the longitudinal relaxation rate of PBNPs to promote their diagnostic capability has become a topic of intense research interest in recent years.

In practical clinical trials, CAs are used to further enhance the sensitivity of the MRI image quality by increasing the relaxation rate around the agents. For $\mathrm{T}_{1} \mathrm{CAs}$, the $\mathrm{R}_{1}$ relaxation rate is defined by [76]:

$$
\mathrm{R}_{1}=1 / \mathrm{T}_{1}=\left(1 / \mathrm{T}_{1}\right)_{0}+\mathrm{r}_{1} \mathrm{C},
$$

where $R_{1}$ is the relaxation rate of the aqueous solution, $T_{1}$ is the relaxation time in the absence of the contrast agent, $C$ is the concentration of the contrast agent $(\mathrm{mM})$, and $\mathrm{r}_{1}$ is its relaxivity $\left(\mathrm{s}^{-1} \mathrm{mM}^{-1}\right)$. According to Equation (1), the $R_{1}$ relaxivity is inversely proportional to the $T_{1}$ and proportional to $r_{1}$ when $C$ is a constant. The $C$ of a $C A$ is inversely proportional to its $r_{1}$ when $R_{1}$ is a constant. Consequently, for a constant $C A$ concentration, shortening $T_{1}$ is a way to increase $r_{1}$. For $C A s$ that satisfy the diagnostic requirements, designing CAs with a large $r_{1}$ is one way to reduce its injection dose in clinical trials. Achieving a larger $r_{1}$ with a smaller amount of injected PBNPs metallic ions is important, as this would reduce possible side effects compared with conventional CAs in biomedical imaging. 
This is based on the premise that the PBNPs remain fully stable under physiological conditions. Hence, it is necessary to carry out systematic toxicity tests on the internalization of the particles in the cells and determine the long-term stability of the PBNPs. Li et al. employed the Glypican-3 antibody to modify PBNPs for targeted MR imaging [33]. Subsequently, their group further demonstrated that PBNPs have acute toxicity in vivo. However, by monitoring the dynamic changes of the biochemical and immunity indicators, their long-term toxicity was determined to be low after short-term exposure [51]. For biomedical imaging application of PBNPs, a good ability for cellular uptake is an important pre-requisite. Shokouhimehr et al. demonstrated the cellular uptake of the PBNPs using MDA MB-231 cells and HeLa incubated with PBNPs. They also confirmed the non-toxic nature of the PBNPs [32]. Perera et al. fabricated PEG-coated Gd@PBNPs with long-term stability for gastrointestinal tract MR imaging. They demonstrated that the increased positive MRI signal in the stomach remained stable for $60 \mathrm{~min}$, and remained visible even after $90 \mathrm{~min}$ via abdominal injection [34].

Inspired by good performance of $\mathrm{Mn}^{2+}, \mathrm{Gd}^{3+}$, and $\mathrm{Fe}^{3+}$ for enhancement of $\mathrm{T}_{1}$-weighted MRI, an effective strategy for improving $r_{1}$ value is to dope metal ions in the PB nanocrystal structure. Typically, the following four areas are important for enhancing the MRI sensitivity and obtaining a good image quality: dopant effects, size control, testing temperature, and shape regulation. (1) Dopant effects: $\mathrm{Mn}^{2+}$ has five unpaired electrons $(\mathrm{J}=5 / 2, \mathrm{~S}=5 / 2, \mathrm{~L}=0), \mathrm{Gd}^{3+}$ has seven unpaired electrons $(\mathrm{J}=7 / 2$, $\mathrm{S}=7 / 2, \mathrm{~L}=0)$, and $\mathrm{Fe}^{3+}$ has five unpaired electrons $(\mathrm{J}=5 / 2, \mathrm{~S}=5 / 2, \mathrm{~L}=0)$, making $\mathrm{Mn}^{2+}$-based PBNPs, $\mathrm{Gd}^{3+}$-based PBNPs, and $\mathrm{Fe}^{3+}$-based PBNPs promising candidates as $\mathrm{T}_{1} \mathrm{CAs}$. Paul et al. reported that the value of $r_{1}$ could increase to $15 \mathrm{mM}^{-1} \mathrm{~s}^{-1}$ via doping $\mathrm{Mn}^{2+}$ in PBNPs, and the $\mathrm{r}_{1}$ value of $\mathrm{Mn}^{2+}$-doped PB was 40 times that of $7 \mathrm{~nm} \mathrm{MnO}$ nanoparticles and about twice that reported for the best $2.5 \mathrm{~nm} \mathrm{MnO}$ nanoparticles [35]. Fétiveau et al. designed two series of ultrasmall PBANPs with different $\mathrm{Gd}^{3+}$ contents for imaging tumors. They obtained outstanding longitudinal relaxivities of $40 \mathrm{mM}^{-1} \mathrm{~s}^{-1}$ (at $1.4 \mathrm{~T}$ ) per $\mathrm{Gd}^{3+}$ and also confirmed that $\mathrm{Fe}^{3+}$ ions also contribute to the overall relaxivity $\left(r_{1}=55 \mathrm{mM}^{-1} \mathrm{~s}^{-1}\right)$ to some extent [36]. (2) Size control: for $T_{1} C A s$, the $r_{1}$ value could be enhanced by increasing the number of bound water molecules $(q)$ and increasing the rotational correlation time (tR) on the basis of the classical Solomon Bloembergen Morgan (SBM) theory [76]. In the small metal ion-doped PBNPs, the metal ions should be located at the surface, making these metal ions sites particularly accessible to water and this increases the number of bound water molecules. Ali et al. synthesized different sizes of $\mathrm{Mn}^{2+}$-doped PBNPs and revealed that the $\mathrm{r}_{1}$ value was equal to 2.58 and $5.30 \mathrm{mM}^{-1} \mathrm{~s}^{-1}$ for sizes of $73 \mathrm{~nm}$ and $61 \mathrm{~nm}$, respectively [37]. (3) Testing temperature: according to SBM, the $r_{1}$ value increased as the temperature decreased because of the increase in the rotational correlation time. The Paul group reported that the $r_{1}$ of $\mathrm{Mn}^{2+}$-doped PBANPs and $\mathrm{Gd}^{3+}$-doped PBANPs increased when the temperature decreased from 37 to $5{ }^{\circ} \mathrm{C}[35,36]$. (4) Choice of shape: hollow mesoporous PBNPs have been demonstrated as excellent drug carriers to load $\mathrm{Mn}^{2+}$ ions and be exposed to an aqueous environment, which can be triggered by the release of $\mathrm{Mn}^{2+}$ in the site of interest (e.g., tumor site). This makes it a smart $\mathrm{T}_{1}$-weighted MRI CA with an ultrahigh relaxivity for tumor diagnosis [38]. Table 1 summarizes the MR relaxivities based on PBNPs for this section.

Table 1. Summary of MR relaxivities based on PBNPs.

\begin{tabular}{|c|c|c|c|c|c|c|c|c|}
\hline NPs & $\begin{array}{c}\text { Approximate } \\
\text { Size (nm) }\end{array}$ & $\begin{array}{l}\text { Surface } \\
\text { Coating }\end{array}$ & Shape & $\begin{array}{c}\mathrm{r}_{1} \\
\left(\mathrm{mM}^{-1} \mathbf{s}^{-1}\right)\end{array}$ & $\begin{array}{c}\mathrm{r}_{2} \\
\left(\mathrm{mM}^{-1} \mathrm{~s}^{-1}\right)\end{array}$ & Field $(\mathrm{T})$ & $\mathrm{T}\left({ }^{\circ} \mathrm{C}\right)$ & Ref. \\
\hline PBNPs & 25 & - & Cubes & $\begin{array}{c}0.2 \\
0.14\end{array}$ & $\begin{array}{l}1.22 \\
2.88\end{array}$ & $\begin{array}{c}1.5 \\
7\end{array}$ & - & [32] \\
\hline $\begin{array}{c}\text { AntiGPC3-PBNPs } \\
\text { Gd@PBNPs }\end{array}$ & $\begin{array}{c}21 \\
24 \pm 9\end{array}$ & $\begin{array}{l}\text { Citrate } \\
\text { PEG }\end{array}$ & $\begin{array}{l}\text { Cubes } \\
\text { Cubes }\end{array}$ & $\begin{array}{l}0.14 \\
16.4\end{array}$ & $\begin{array}{c}11.73 \\
20.9\end{array}$ & $\begin{array}{l}9.4 \\
1.4\end{array}$ & $\begin{array}{l}20 \\
37\end{array}$ & $\begin{array}{l}{[33]} \\
{[34]}\end{array}$ \\
\hline Mn@PBNPs & 5.5 & Dextain & Sphere & $\begin{array}{c}12.9 \\
10\end{array}$ & $\begin{array}{c}- \\
15\end{array}$ & 3 & $\begin{array}{c}5 \\
37\end{array}$ & [35] \\
\hline $\begin{array}{c}\text { Gd@PBNPs } \\
(\mathrm{GdFeFe})\end{array}$ & 3.9 & Dextain & Sphere & $\begin{array}{l}81 \\
55\end{array}$ & $\begin{array}{c}- \\
77\end{array}$ & 1.4 & $\begin{array}{c}5 \\
37\end{array}$ & [36] \\
\hline Mn@PBNPs & $71 / 63$ & - & Cubes & $2.58 / 5.3$ & - & 4.7 & RT & [37] \\
\hline Mn@HMPBNPs & 290 & PVP & Cubes & 3.0 & - & 7.0 & 25 & [38] \\
\hline
\end{tabular}




\subsection{Photoacoustic Imaging}

The photoacoustic imaging (PAI) technique is a broadly applicable noninvasive imaging modality; transient acoustic waves are generated via the absorption of NIR in biological tissues, which can then be detected using a traditional ultrasound transducer [77-80]. PAI has numerous advantages including a high spatial resolution, strong contrast, noninvasiveness, real-time imaging, low cost, and the ability for both endogenous and exogenous imaging, which has attracted wide attention for applications involving the imaging of biological tissues [44]. However, the low laser absorption of the endogenous chromophore leads to a weak signal, which is a major obstacle for deep tissue imaging [81]. Choosing a good NIR-absorbing photoacoustic imaging contrast agent (PAICA) is a necessary condition to ensure the high-quality imaging of biological tissues.

The PBNPs with a blue appearance can cause transient thermoelastic expansion via strong NIR absorption and provide ultrasonic signals for PAI [39]. Several groups have demonstrated the feasibility of PBNPs as a PAICA. Liang et al. first demonstrated that PBNPs have efficient absorption of NIR at $765 \mathrm{~nm}$, which is within the optical window for the deepest light penetration in tissues and can be a superior PAICA [82]. Zheng et al. revealed that PB provided a distinct photoacoustic signal in the tumor and the signals showed a time-dependent increase [83]. Xu et al. developed an "in situ modification" synthesis to obtain good physiological stability of PB for over 90 days using PVP and $\mathrm{K}_{3}\left[\mathrm{Fe}(\mathrm{CN})_{6}\right]$. They further reported that the PAI signal intensity of PB was brighter than the control group in tumor-bearing mice, and it exhibited an obvious concentration-dependence with injection of PB [41].

The good photothermal stability of PBNPs after NIR irradiation is vital for improving the photoacoustic signal-to-noise ratio. Dumani et al. synthesized $\mathrm{PB}$ nanocubes using superparamagnetic iron oxide nanoparticles (SPION) as precursors and verified their photothermal stability under pulsed laser irradiation. Unlike gold nanorods (degradation at $8.5 \mathrm{~mJ} \cdot \mathrm{cm}^{-2}$ ) and silica-coated gold nanorods (degradation at $13 \mathrm{~mJ} \cdot \mathrm{cm}^{-2}$ ), the PB nanocubes (PBNCs) displayed no degradation of the photoacoustic signal (up to $28 \mathrm{~mJ} \cdot \mathrm{cm}^{-2}$ ). Importantly, the photoacoustic signal from the injection of PBNPs was approximately five-fold higher than the control injection after $700 \mathrm{~nm}$ laser irradiation [40]. More importantly, during the course of clinical treatment, PBNPs have been used as a stem cell tracer to monitor the dynamic process of migration and differentiation owing to cellular internalization via endocytosis. Stem cells have some ability for migration, differentiating into various functional cells, interaction with pathology, and self-renewal that are vital to understanding the status of disease recovery. Kubelick et al. demonstrated that PBNCs have ability to label stem cells and generate contrast for PAI. Their results indicated that PAI with PBNCs can provide real-time feedback on mesenchymal stem cells (MSCs) delivery and motivated an approach for stem cell tracking in the spinal cord [42]. The PAI technique via PBNPs as a CA to label bone MSCs has also been exploited for imaging traumatic brain injury and monitoring the recovery process [43].

\section{PBNPs for Drug Delivery}

An ideal drug delivery system is required to have low cytotoxicity, excellent stability and biocompatibility, large loading capacity, and responsive release [84]. Hollow or mesoporous PBNPs with large intrinsic internal pore volumes, tunable size, and easy synthesis have been successfully employed as carriers to deliver drugs [16]. However, bare hollow PBNPs (HMPBNPs) would lead to low therapeutic efficacy and high toxicity because of drug leakage, uncontrolled drug delivery, and a low immune evading ability. Recently, HMPBNPs with surface modification have been proposed as a new class of drug delivery system for chemotherapy. Table 2 summarizes some PBNPs for drug delivery.

For specific tumor chemotherapy, a multi-responsive smart drug delivery system is expected to enhance antitumor treatment and reduce toxicity via prolonging the systemic circulation time, decreasing the identification of monocytes and macrophages, targeted accumulation at the tumor site, and controlled drug release. Recently, PBNPs combined with natural biomaterials, such as red 
blood cell (RBC) membranes have drawn research attention to facilitate the accumulation of drugs at tumor sites via passive targeting and extension of the circulation time. Liu et al. first constructed a nanodrug system using RBC membrane-coated HMPBNPs to extend the blood circulation time to $10 \mathrm{~h}$ and increase the immune evasion ability to more than $60 \%$ for tumor targeting and long circulation therapy. Additionally, active targeting drug delivery systems are most widely used for tumor therapy to improve the selectivity and specificity via chemical synthetic strategies. Hyaluronic acid (HA) was introduced to bind to the CD44 receptor of breast cancer cells and increase the tumor-targeted accumulation of the drug. Based on the effective accumulation of nanocomposites at tumor sites, anti-tumor drug gamabufotalin (CS-6) was loaded by taking advantage of the high surface volume of HMPBNPs for chemotherapy [46].

In addition, controlled release of PBNPs-based nanocomposites for tumor therapy can be triggered via chemical (pH or redox) or physical (heat or light) stimuli [85]. Doxorubicin (DOX), as a chemotherapy drug with excellent anti-tumor and $\mathrm{pH}$-responsive effects, is used for the assessment of the accumulation at tumor sites and the release pattern in the drug delivery system. Xiao et al. used the erythrocyte membrane (EM) and folate (FA) to modify spheric and cubic hollow mesopores PBNPs (SCPBNPs) and introduce DOX. The results demonstrated the potential in the SCPBNPs@DOX@EM@FA treatment group for reducing macrophage phagocytosis and immune response, extending the blood circulation time (3.3-fold) and the half-life (2.5-fold), and improving targeting (2.5-fold) compared with the bare SCPBNPs treatment group for tumor therapy [47]. Based on the pH-responsive effect of DOX, a bimetallic NiCo-PB analog (NiCo-PBA) doped $\mathrm{Tb}^{3+}$ was embedded in a PEGMA layer and then anchored with the AS1411 aptamer and DOX; it demonstrated a pH-responsive capability, controlled drug release within cancer cells, and enhanced tumor-targeted delivery of DOX [86]. In another study, Li et al. developed DOX-encapsulated PBNPs coupled pentacarbonyl iron $\left(\mathrm{Fe}(\mathrm{CO})_{5}\right)$ as a $\mathrm{CO}$ producer and decorated it with hydrophilic polymers via a layer-by-layer technique to enhance its aqueous stability. They further demonstrated that $\mathrm{Fe}(\mathrm{CO})_{5}$ was cleaved at $42{ }^{\circ} \mathrm{C}$ to release $\mathrm{CO}$, which caused mitochondrial collapse, inhibition of APT-dependent drug efflux, and enhanced drug accumulation in the cancer cells to overcome multidrug resistance and improve the anti-cancer effect under the NIR light irradiation $\left(808 \mathrm{~nm}, 0.5 \mathrm{~W} / \mathrm{cm}^{2}\right)$ [87].

Table 2. Summary of PB-based nanoparticles for drug delivery.

\begin{tabular}{|c|c|c|c|c|c|c|c|}
\hline Name & Drug Release & $\begin{array}{l}\text { Size } \\
(\mathrm{nm})\end{array}$ & Targeting & $\begin{array}{l}\text { Anti-Tumor } \\
\text { Drug }\end{array}$ & $\begin{array}{l}\text { Loading } \\
\text { Efficiency } \\
(\%)\end{array}$ & $\begin{array}{l}\text { Circulation } \\
\text { Time (h) }\end{array}$ & Ref. \\
\hline $\begin{array}{l}\text { HA@RBC } \\
@ P B @ C S-6\end{array}$ & $\begin{array}{c}\mathrm{pH}-/ \text { photo- } \\
\text { responsive release }\end{array}$ & 140 & $\mathrm{HA}, \mathrm{RBC}$ & CS-6 & - & 10 & [46] \\
\hline $\begin{array}{c}\text { PB@DOX @EM@FA } \\
\text { NPs }\end{array}$ & $\begin{array}{l}\mathrm{pH}-/ \text { photo- } \\
\text { responsive release }\end{array}$ & 185 & FA, EM & DOX & 130.69 & 48 & [47] \\
\hline $\begin{array}{c}\text { NiCo-PBA@Tb }{ }^{3+} \\
\text { @PEGMA } \\
\text { @AS1411@DOX }\end{array}$ & $\begin{array}{l}\mathrm{pH}-\text { responsive } \\
\text { release }\end{array}$ & 173 & As1411 & DOX & 77.2 & - & [86] \\
\hline $\begin{array}{l}\text { PAH@PAA@PEG@PB } \\
\text { @CO@DOX }\end{array}$ & $\begin{array}{l}\mathrm{pH}-/ \mathrm{NIR} \text { light } \\
\text { release }\end{array}$ & 128 & $\begin{array}{l}\text { Passive } \\
\text { targeting }\end{array}$ & DOX & 14.5 & - & [87] \\
\hline
\end{tabular}




\section{PBNPs for Tumor Photothermal and Photodynamic Therapy}

This section may be divided by subheadings. It should provide a concise and precise description of the experimental results, their interpretation as well as the experimental conclusions that can be drawn. In clinical tumor therapy, photothermal therapy (PTT) activated using NIR light irradiation has attracted significant attention because of its advantages, such as deep tumor penetration, non-invasiveness, and precise remote control [88]. PBNPs have high optical absorption properties in the NIR region from 650 to $900 \mathrm{~nm}$ because of intervalence charge transfer between $\mathrm{Fe}^{2+}$ and $\mathrm{Fe}^{3+}$ in the $\mathrm{PB}$ structure, which can realize tumor eradication via the cytotoxic heat generated from PBNPs [89]. Fu et al. first reported PBNPs as new PPTCAs to treat tumors under NIR irradiation (at $808 \mathrm{~nm}$ ). They demonstrated that PBNPs have high molar extinction coefficients $\left(1.09 \times 10^{9} \mathrm{~m}^{-1} \mathrm{~cm}^{-1}\right)$ that are of the same order of magnitude as conventional Au nanorods $\left(5.24 \times 10^{9} \mathrm{~m}^{-1} \mathrm{~cm}^{-1}\right)$, which can decrease tumor cell viability to $10 \%$ after treatment using NIR irradiation [90]. In addition, the good photostability, biocompatibility, and dispersibility of the PBNPs-based nanocomposites under physiological conditions have promoted their development as PTTCAs for tumor treatment.

As a PTTCA, the high photothermal conversion efficiency of PBNPs is vital for increasing tumor treatment efficiency, and this is determined by their chemical composition, size and irradiation time, and the power and photon excitation mode. Changing the chemical composition of PBNPs by doping with metal ions and coating with polyethylene glycol could promote the photothermal conversion efficiency and increase the stability under physiological conditions. Coating PBNPs on $\mathrm{NaNdF}_{4}$ nanoparticles could increase photothermal conversion efficiency, currently at $60.8 \%$ under $808 \mathrm{~nm}$ laser irradiation, via the generation of new cross relaxation pathways between the $\mathrm{Nd}^{3+}$ ions and PBNPs compared with stand-alone NdNPs and PBNPs [89,91,92]. Doping lanthanide ions into PBNPs was achieved via a simple method, and it was used to improve the photothermal conversion efficiency (PBNPs-ytterbium, 55\%) by changing the electron density of the cyanide bonds in PBNPs and producing luminescence for optical super resolution imaging in deeper tissue (PBNPs-erbium) [89,93]. In another study, Shou et al. demonstrated that the particle size of the PBNPs could be controlled by $\mathrm{Zn}^{2+}$ doping (PBZnNPs $(\mathrm{n} \%))$ and the photothermal conversion efficiency decreased as the particle size increased and as the irradiation time and power decreased [94]. Additionally, it has been demonstrated that two photon excitation (TPE) can enable improved penetration depth and laser focus compared with the common single photon excitation (SPE) mode, which can also influence the PTT efficiency. For this reason, Ali et al. investigated the efficiency of combined PTT and chemotherapy to eradicate tumor cells and clearly reported a significant advantage of TPE laser irradiation over SPE irradiation under the same experimental conditions treated with nanoparticles (Figure 3). Data showed that, in the case of pulsed TPE at $808 \mathrm{~nm}, 91 \%$ of cell death was found with $1 @$ DOX $24 \mathrm{~h}$ after irradiation (Figure 3a), but the cells treated with $1 @$ DOX only showed $35 \%$ of cell death after $24 \mathrm{~h}$ of irradiation $(808 \mathrm{~nm}$, $2.5 \mathrm{~W} / \mathrm{cm}^{-2}$ ) (Figure 3b)[95].

Photodynamic therapy (PDT) that is minimally invasive and simple has also been widely studied for clinical treatment of localized and superficial tumors by generating excess reactive oxygen species (ROS) to induce cell death. The characteristics of hypoxia in solid tumors result in invasion and metastasis of tumor cells and greatly limit the anti-tumor effect of PDT treatment [96]. It has been reported that high $\mathrm{H}_{2} \mathrm{O}_{2}$ levels in the tumor microenvironment are an appropriate source for $\mathrm{O}_{2}$ production [97]. PBNPs were found to possess catalase-like activity via the Fenton reaction, which can catalyze $\mathrm{H}_{2} \mathrm{O}_{2}$ into $\mathrm{O}_{2}[98,99]$. The generated $\mathrm{O}_{2}$ can effectively support the PDT of tumors and reduce tumor growth and metastasis by decreasing the tumor hypoxia situation. Thus, PBNPs have been extensively used as catalysts to improve the tumor treatment efficacy in PDT. Zhang et al. demonstrated that HA with a macrophage transformation property (pro-tumor $\mathrm{M}_{2}$ to anti-tumor $\mathrm{M}_{1}$ ) modified HMPBNPs (HA-PB) can catalyze $\mathrm{H}_{2} \mathrm{O}_{2}$ for $\mathrm{O}_{2}$ self-supplied PDT and inhibit tumor proliferation. Subsequently, the photosensitizer indocyanine green (ICG) was loaded into HA-PB to realize the production of a singlet oxygen $\left({ }^{1} \mathrm{O}_{2}\right)$ under NIR irradiation with a $808 \mathrm{~nm}$ laser for tumor PDT [50]. Moreover, PBNPs are also expected to control $\mathrm{H}_{2} \mathrm{O}_{2}$ decomposition within the tumor 
by local temperature variation of the PBNPs under NIR laser irradiation to improve the therapeutic effect via the combination of PDT and PTT. Wang et al. realized the photothermally controlled improvement of hypoxic condition in cancer cells and tumor tissues using PB@SiO $2-\mathrm{PEG}-\mathrm{ZnPc}$ (PSPZP) NCs. Figure 4 a showed the synthetic process of PSPZP NCs with enhanced photo-induced $\mathrm{O}_{2}$ and ${ }^{1} \mathrm{O}_{2}$ generation. As shown in Figure $4 \mathrm{~b}$, abundant $\mathrm{O}_{2}$ bubbles were formatted immediately once the PSPZP NCs were added into $\mathrm{H}_{2} \mathrm{O}_{2}$ solution, and the catalytic reaction rate showed an obvious trend of growth with the increase of temperature from $25^{\circ} \mathrm{C}$ to $43^{\circ} \mathrm{C}$. Further, they measured the generation of $\mathrm{O}_{2}$ (Figure 4c), and the data showed that the generated $\mathrm{O}_{2}$ by $P B N P s$ under $43{ }^{\circ} \mathrm{C}$ was 1.95 times that under $25^{\circ} \mathrm{C}$ with $671 \mathrm{~nm}$ laser irradiation. Since improved $\mathrm{H}_{2} \mathrm{O}_{2}$ decomposition at higher temperature would increase PDT efficiency of PSP NCs by accelerating $\mathrm{O}_{2}$ supply, they observed lower cell viability with the increase of temperature after irradiation (Figure 4d), More importantly, the constructed nanoplatform could realize significant tumor inhibition in mice compared with PDT or PTT treatment (Figure 4e) [100]. In view of these facts, designing a multi-responsive smart drug delivery system with a PBNPs-based nanocomposite using a combined PTT/PDT technique is of interest for overcoming the limitations of PDT, such as $\mathrm{O}_{2}$ dependence non-selectivity, and the high laser power requirements of PTT [101-103].

(a)

(b)
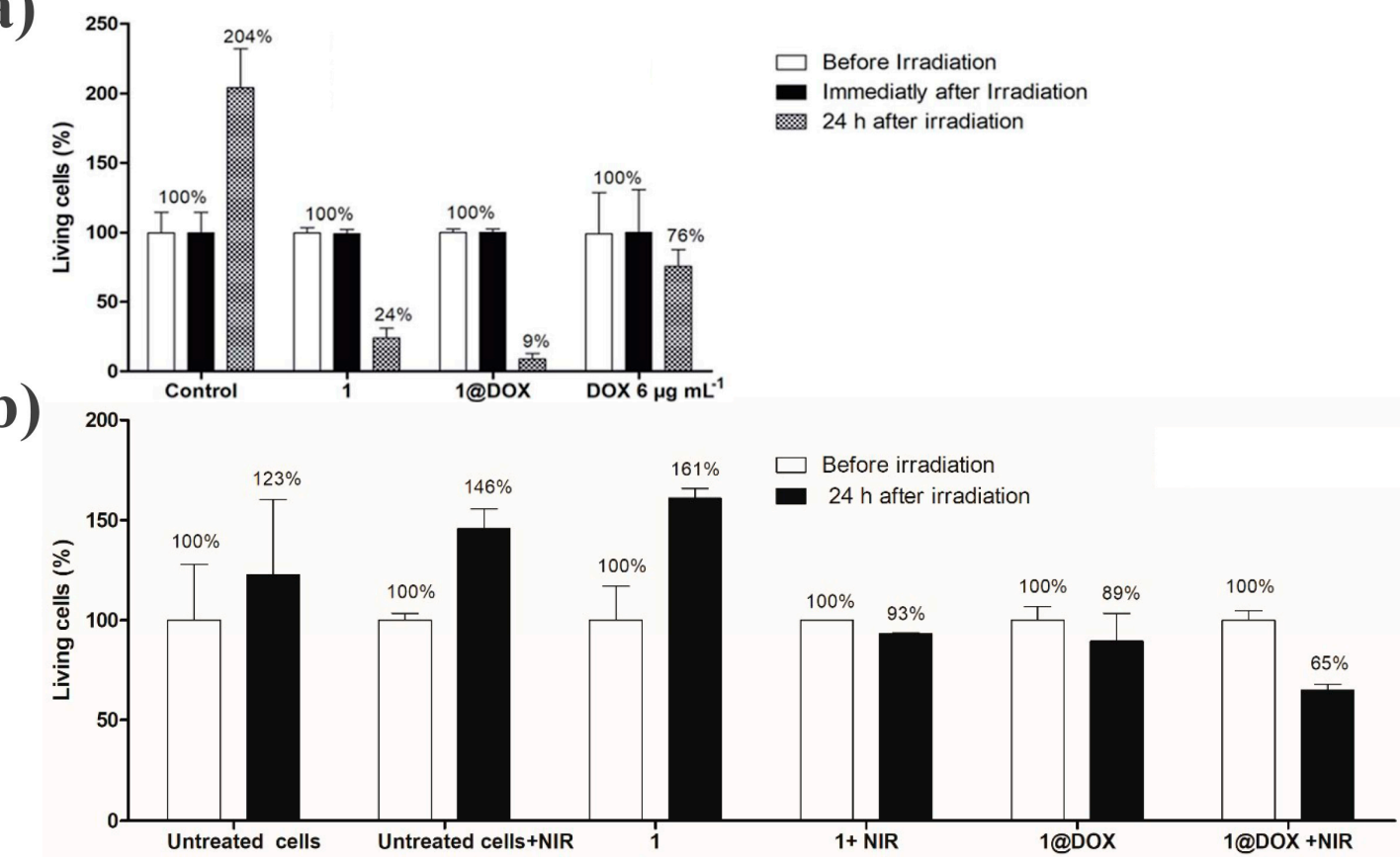

Figure 3. Cell counting (\%) of living MDA-MB-231 cells treated with $\mathrm{Mn}^{2+}$-doped PBNPs@DOX (1@DOX) and $\mathrm{Mn}^{2+}$-doped PBNPs (1) at $50 \mathrm{mg} / \mathrm{mL}$ and free DOX before irradiation and $24 \mathrm{~h}$ after irradiation with a TPE laser at $808 \mathrm{~nm}(3.7 \mathrm{~W}, 5 \%$ of total laser power) for $10 \mathrm{~min}$ (a) and with SPE at $808 \mathrm{~nm}\left(2.5 \mathrm{~W} \mathrm{~cm}^{-2}\right)$ for $30 \mathrm{~min}(\mathbf{b})$, adapted with permission from ref. [95]. 
(a)

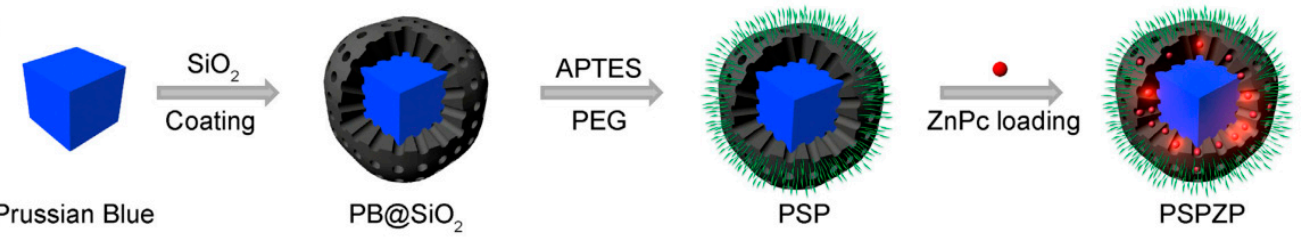

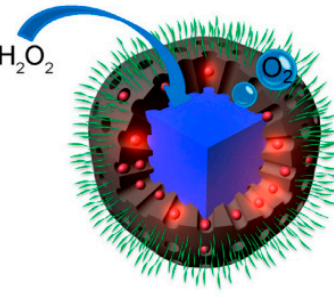

(b)

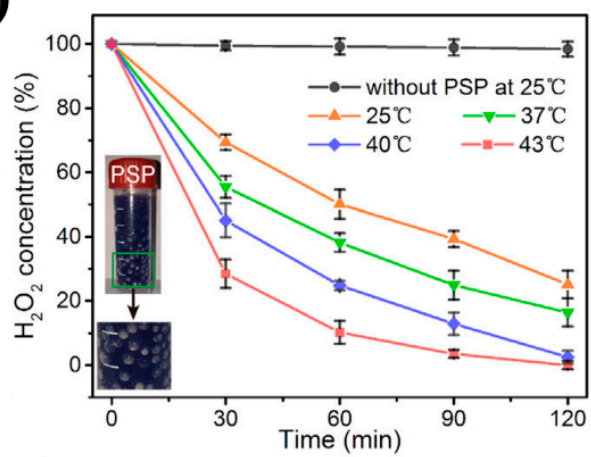

(d)

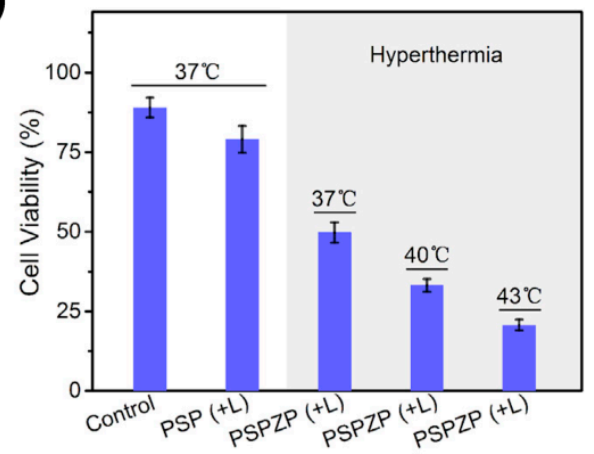

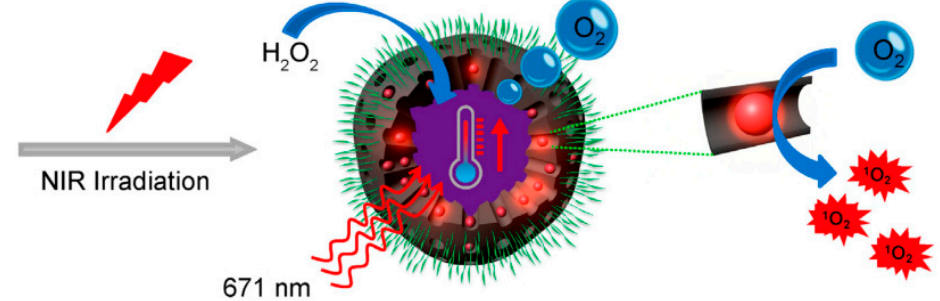

(c)

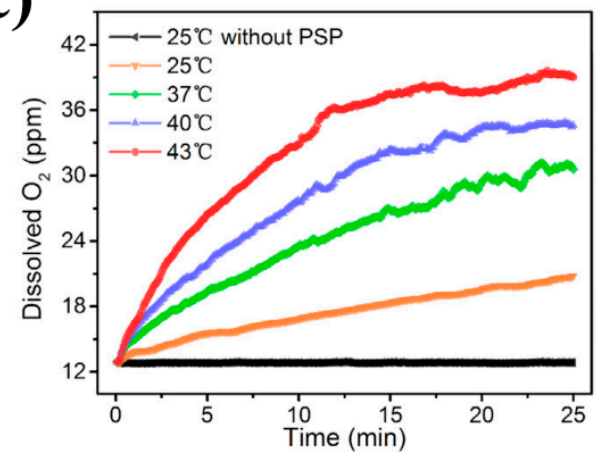

(e)

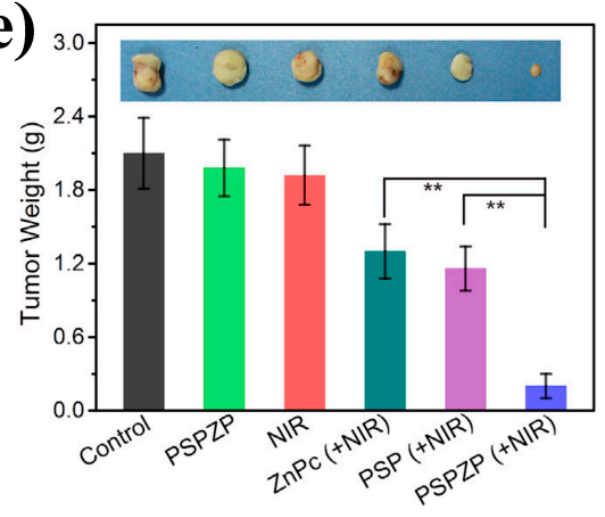

Figure 4. (a) Schematic of the synthetic procedure and photo-enhanced therapy of the PSP NCs; (b) Decomposition of $\mathrm{H}_{2} \mathrm{O}_{2}$ and (c) $\mathrm{O}_{2}$ generation treated with PSP NCs or not treated; (d) Relative viabilities of 4T1 cells incubated with PSP or PSPZP NCs; (e) Average weights of tumors collected from mice at the end of treatments, adapted with permission from ref. [100]. ${ }^{* *} p<0.01$.

\section{PBNPs for Tumor Imaging-Guided Therapy}

Imaging-guided therapy is a combination of medical therapy and diagnostic imaging to monitor the accumulation of a therapeutic agent within the tumor or enhance the therapeutic effects while decreasing the side effects during tumor treatment. It has shown great potential for drug delivery and image-guided minimally invasive therapy. For this reason, PBNPs-based imaging-guided therapy could decrease severe side effects such as a strong light sensitivity, normal cells lesions, and drug resistance in patients. It could also enhance therapeutic efficiency via association of the image-guided PTT or PDT technique with chemotherapy and develop a personalized synergistic therapy with real-time imaging diagnosis and tumor treatment. Table 3 summarizes the recent imaging-guided therapy strategies developed based on PBNPs. 
Table 3. Summary of therapeutic PBNPs-based nanomaterials for imaging-guided tumor treatment.

\begin{tabular}{|c|c|c|c|c|c|c|}
\hline Formulations & $\begin{array}{c}\text { Treatment } \\
\text { Approaches }\end{array}$ & Imaging & Targeting & Cell Lines & $\begin{array}{c}\text { Laser } \\
\text { Irradiation }\end{array}$ & Ref. \\
\hline $\begin{array}{l}\text { antiglypican-3- } \\
\text { PBNPs }\end{array}$ & PTT & MR & Antiglypican-3 & $\begin{array}{l}\text { HepG2; } \\
\text { HL-7702 } \\
\text { cells }\end{array}$ & $\begin{array}{c}808 \mathrm{~nm} \text { laser } \\
\left(2 \mathrm{~W} \mathrm{~cm}^{-2}\right. \\
10 \mathrm{~min})\end{array}$ & [33] \\
\hline $\begin{array}{c}\text { PVP or } \\
\text { dextran-coated } \\
\mathrm{Gd}^{3+} @ P B N P s\end{array}$ & PTT & MR; PA & - & CT26 cells & $\begin{array}{c}808 \mathrm{~nm} \text { laser } \\
\left(1 \mathrm{~W} \mathrm{~cm}^{-2}\right. \\
5 \mathrm{~min})\end{array}$ & [36] \\
\hline $\begin{array}{l}\mathrm{Mn}^{2+} \text {-doped } \\
\text { PBNPs }\end{array}$ & PTT & MR & - & $\begin{array}{l}\text { MDA-MB- } \\
231 \text { cells }\end{array}$ & $\begin{array}{l}\text { Two-photon } \\
\text { light at } 808 \\
\mathrm{~nm}(3.7 \mathrm{~W}, \\
10 \mathrm{~min})\end{array}$ & [37] \\
\hline $\begin{array}{l}\text { PVP-coated } \\
\text { HMPB-Mn }\end{array}$ & $\begin{array}{c}\text { Chemothermal } \\
\text { therapy }\end{array}$ & MR & - & $4 \mathrm{~T} 1$ cells & $\begin{array}{c}808 \mathrm{~nm} \text { laser } \\
\left(1 \mathrm{~W} \mathrm{~cm}^{-2}\right. \\
5 \mathrm{~min})\end{array}$ & [38] \\
\hline $\begin{array}{c}\mathrm{Au} @ P B @ \mathrm{Cu}_{2} \mathrm{O} \\
@ B P Q D s / P A H N C s .\end{array}$ & PTT/PDT & MR; PA; FL & - & HeLa cells & $\begin{array}{c}650 \mathrm{~nm}^{2} \text { laser } \\
\left(1.5 \mathrm{~W} \mathrm{~cm}^{-2}\right. \\
5 \mathrm{~min})\end{array}$ & [83] \\
\hline PBNPs & PTT & $\mathrm{MR} / \mathrm{PA}$ & - & 4T1 cells & $\begin{array}{c}808 \mathrm{~nm} \text { laser } \\
\left(0.8 \mathrm{~W} \mathrm{~cm}^{-2}\right. \\
5 \mathrm{~min})\end{array}$ & [41] \\
\hline $\begin{array}{c}\text { PB@DOX } \\
@ E M @ F A N P s\end{array}$ & $\begin{array}{l}\text { Chemo- } \\
\text { photothermal } \\
\text { therapy }\end{array}$ & PA; FL & Folic acid & HeLa cells & $\begin{array}{c}808 \mathrm{~nm} \text { laser } \\
\left(0.8 \mathrm{~W} \mathrm{~cm}^{-2}\right. \\
5 \mathrm{~min})\end{array}$ & [47] \\
\hline $\begin{array}{c}\text { PBNPs@Fe }(\mathrm{CO})_{5} \\
@ \mathrm{DOX}\end{array}$ & $\begin{array}{c}\text { Chemo- } \\
\text { photothermal- } \\
\text { photodynamic } \\
\text { therapy }\end{array}$ & US & - & $\begin{array}{l}\text { MCF-7/ } \\
\text { ADR cells }\end{array}$ & $\begin{array}{c}808 \mathrm{~nm} \text { laser } \\
\left(0.5 \mathrm{~W} \mathrm{~cm}^{-2}\right. \\
15 \mathrm{~min})\end{array}$ & [87] \\
\hline $\mathrm{NdNdF}_{4} @ \mathrm{PBNPs}$ & PTT & PA & - & HeLa cells & $\begin{array}{c}808 \mathrm{~nm} \text { laser } \\
\left(0.6 \mathrm{~W} \mathrm{~cm}^{-2}\right. \\
10 \mathrm{~min})\end{array}$ & [91] \\
\hline $\mathrm{Zn}^{2+} @ \mathrm{PBNPs}$ & PTT & MR & - & $4 \mathrm{~T} 1$ cells & $\begin{array}{c}808 \mathrm{~nm} \text { laser } \\
\left(1 \mathrm{~W} \mathrm{~cm}^{-2}\right. \\
5 \mathrm{~min})\end{array}$ & [94] \\
\hline $\begin{array}{l}\mathrm{PB} @ \mathrm{SiO}_{2-} \\
\text { PEG-ZnPc }\end{array}$ & PDT; PTT & PET; PA & - & $4 \mathrm{~T} 1$ cells & $\begin{array}{c}671 \mathrm{~nm} \text { laser } \\
\left(0.4 \mathrm{~W} \mathrm{~cm}^{-2}\right. \\
5 \mathrm{~min})\end{array}$ & [100] \\
\hline $\mathrm{Gd}^{3+} @ \mathrm{PBNPs}$ & PTT & PA; MR & - & $4 \mathrm{~T} 1$ cells & $\begin{array}{c}808 \mathrm{~nm} \text { laser } \\
(0.58 \mathrm{~W} \\
\mathrm{cm}^{-2} \\
10 \mathrm{~min})\end{array}$ & [104] \\
\hline $\mathrm{MnO}_{2} @ P B N P s$ & PTT & $\begin{array}{c}\text { PA; T1/T2 } \\
\text { weighted } \\
\text { MRI }\end{array}$ & - & MCF-7 cells & $\begin{array}{c}808 \mathrm{~nm} \text { laser } \\
\left(2.5 \mathrm{~W} \mathrm{~cm}^{-2}\right. \\
5 \mathrm{~min})\end{array}$ & [105] \\
\hline Au@PB & PTT & $\mathrm{CT} ; \mathrm{PA}$ & - & HT-29 cells & $\begin{array}{c}808 \mathrm{~nm} \text { laser } \\
\left(1.5 \mathrm{~W} \mathrm{~cm}^{-2},\right. \\
10 \mathrm{~min})\end{array}$ & [106] \\
\hline Au@PB-HA & PDT; PTT & MR; SERS & Hyaluronic acid & $4 \mathrm{~T} 1$ cells & $\begin{array}{c}808 \mathrm{~nm} \text { laser } \\
\left(2 \mathrm{~W} \mathrm{~cm}{ }^{-2}\right. \\
10 \mathrm{~min})\end{array}$ & [107] \\
\hline $\begin{array}{l}\text { CD-decorated } \\
\text { PBNP }\end{array}$ & PTT & FL & - & C6 cells & $\begin{array}{c}808 \mathrm{~nm} \text { laser } \\
\left(0.8 \mathrm{~W} \mathrm{~cm}^{-2}\right. \\
10 \mathrm{~min})\end{array}$ & [108] \\
\hline
\end{tabular}


Table 3. Cont.

\begin{tabular}{|c|c|c|c|c|c|c|}
\hline Formulations & $\begin{array}{c}\text { Treatment } \\
\text { Approaches }\end{array}$ & Imaging & Targeting & Cell Lines & $\begin{array}{c}\text { Laser } \\
\text { Irradiation }\end{array}$ & Ref. \\
\hline PB-BSA-ICG & PDT; PTT & MR; FL & - & SCC7 cells & $\begin{array}{c}808 \mathrm{~nm} \text { laser } \\
\left(1 \mathrm{~W} \mathrm{~cm}^{-2}\right. \\
10 \mathrm{~min})\end{array}$ & [109] \\
\hline HMPBs-DOX/PFH & $\begin{array}{c}\text { Chemo-HIFU } \\
\text { therapy }\end{array}$ & PA; US & - & VX2 cells & - & [110] \\
\hline $\begin{array}{c}\text { FeOCl@PB } \\
@ P D A @ B P Q D s\end{array}$ & CDT; PDT; PTT & PA; MR; US & - & 4T1 cells & $\begin{array}{c}650 \mathrm{~nm} \text { laser } \\
\left(1.5 \mathrm{~W} \mathrm{~cm}^{-2}\right. \\
5 \mathrm{~min})\end{array}$ & [111] \\
\hline
\end{tabular}

As mentioned before, PBNPs-based nanoparticles as theranostics probes have been extensively used for tumor treatment with a single imaging modality, such as MRI or PAI [37,39,94,112,113]. Nevertheless, obtaining complete information and synchronous imaging diagnosis within the tumor using single-modal imaging is still a great challenge. For example, PAI has the advantages of excellent sensitivity, high spatial resolution, and real-time imaging, but it has a limited tissue penetration depth because of optical scattering $[114,115]$. MRI is a noninvasive technique for early tumor diagnosis because of its high spatial resolution and deep tissue penetration, but it still has the issue of poor sensitivity [116]. Combining two or more imaging modalities can allow for accurate collection of complementary and synchronous information on the same region of pathological tissue [117]. Multifunctional PBNPs, as contrast agents for various imaging modalities, with a high photothermal conversion efficiency, catalase-like activity, and drug loading capacity, have been explored for their synergistic effects with combined multimodal imaging-guided therapy for tumor treatment. Cai et al. reported a new strategy for functionalizing PB to obtain the controllability of the maximum absorbance in the NIR of PB from 710 to 910 nmby incorporating $\mathrm{Gd}^{3+}$ ions into the lattice sites of $\mathrm{PB}$, meeting the demands of good spatial resolution and sensitivity, deep tissue penetration, real-time PAI/MRI, and excellent PTT performance, $\mathrm{Gd}^{3+}$-doped PBNPs showed an ability for scavenging ROS and avoiding oxidative stress injury to normal cells, demonstrating good biosafety and completely eliminating the tumor [104]. In another work, Peng et al. successfully fabricated a $\mathrm{PB} / \mathrm{MnO}_{2}$ nanosystem that had efficient $\mathrm{O}_{2}$ production to oxygenate deoxygenated hemoglobin within the tumor tissue and improve the diamagnetic $\mathrm{T}_{2}$ signal intensity, which can be used as $\mathrm{T}_{2}$ modal contrast agent and also as a $\mathrm{T}_{1} / \mathrm{PAI}$ for imaging-guided PTT and oxygen regulation of the tumor [105].

In addition to MRI, integrating photosensitizers (PSs) in PAI-guided therapy is a common strategy; these include plasmonic, ICG, and semiconductor nanomaterials into PBNPs to obtain multiplex phototherapy and new imaging modalities under NIR laser irradiation. Core/shell nanoparticles of Au@PBNPs were fabricated for X-ray computed tomography (CT)/PA imaging-guided PTT of tumors. The Au core served as a CA for CT imaging to provide high resolution and 3D images, and the external PB shell afforded PAI and PTT effects [106]. Moreover, AuNPs are excellent surface-enhanced raman scattering (SERS) substrates that can significantly enhance the signal-to-background ratio (SBR) of the incorporated PBNPs. For this reason, Zhu et al. further modified Au@PBNPs by grafting HA for enhanced accumulation at the tumor site. The constructed theranostic agent possessed an enhanced $\mathrm{T}_{1}$ and $\mathrm{T}_{2}$ signal, stable zero-background single SERS emission, and photothermal/photodynamic conversion under NIR light irradiation, allowing for the realization of SERS/MR imaging-guided PDT/PTT for targeted-tumor treatment [107]. In addition, Peng et al. designed carbon dot-decorated PBNPs with a stable green photoluminescent property, efficient photothermal conversion capacity, and excellent biocompatibility. It showed excellent theranostics efficiency for fluorescence (FL) imaging-guided PTT for tumor treatment [108]. Conjugating ICG onto the surfaces of the PBNPs also has potential for application as a nanotheranostic agent for $\mathrm{T}_{1}$-weighted MR and FL imaging-guided PDT/PTT of tumors [109]. 
PBNPs incorporating different types of ultrasound contrast agents (UCAs) that serve as theranostic agents for multi-modal imaging and tumor therapy have made great progress. Jia et al. prepared a nanotheranostic agent for ultrasound imaging-guided PTT of tumors based on perfluoropentane encapsulated HMPBNPs. The heat produced by the PBNPs could cause gasification of the perfluoropentane to generate bubbles under NIR laser irradiation, which could improve the sensitivity in the tissue of interest during ultrasound imaging (USI) [118]. However, USI with a poor spatial resolution and contrast generally limits the early diagnosis of tumors [119,120]. Zhang et al. constructed perfluorohexaneen capsulated HMPBNPs loaded DOX for PAI/USI dual-modal imaging-guided chemo-high-intensity focused ultrasound (HIFU) therapy. HIFU could trigger DOX release and raise the temperature rapidly by depositing acoustic energy in the focal volume, which promoted the treatment of deep solid tumors. Dual-modal imaging overcame the limitations of USI by combining sensitive optical contrast and a high ultrasonic resolution [110]. More importantly, PBNPs can catalyze the breakdown of $\mathrm{H}_{2} \mathrm{O}_{2}$ into oxygen bubbles in the tumor, which changed the acoustic impedance of the tissue to make it detectable by USI [99]. Zhang et al. prepared an integrated nanoplatform of $\mathrm{Mn}^{2+}$-doped iron oxychloride (FeOCl) nanorods coated with PBNPs, polydopamine (PDA), and black phosphorus quantum dots (BPQDs), which could serve as MRI/PAI/USI agents for tri-modal imaging-guided CDT/PTT/PDT of tumors. Thereinto, the PBNPs, $\mathrm{FeOCl}$, and $\mathrm{Mn}^{2+}$ with catalase-like activity could provide $\mathrm{O}_{2}$ for $\mathrm{O}_{2}$ self-supplied PDT by catalyzing the $\mathrm{H}_{2} \mathrm{O}_{2}$ within solid tumors. FeOCl catalysts had a high yield of hydroxyl radicals $(\bullet \mathrm{OH})$ by decomposing the $\mathrm{H}_{2} \mathrm{O}_{2}$ in chemodynamic therapy (CDT), and BPQDs enabled the transformation of $\mathrm{O}_{2}$ into ${ }^{1} \mathrm{O}_{2}$ to enhance PDT [111].

Therefore, these theranostic agents hold promise for achieving a prolonged systemic circulation time, targeted accumulation at tumor sites, remote controlled drug release, and noninvasive therapy of tumors, which could increase the tumor selectivity and reduce side-effects. Additionally, they can also be exploited to provide tumor results and guidance on the timing and quantity of tumor treatment because of their imaging capabilities.

\section{Conclusions}

This review provides a summary of strategies that use PBNPs as an electron transfer mediator and as a promising theranostic agent for several biomedical applications involving tumors. We focused on the feasibility of using PBNPs as electrocatalysts to enhance the diagnostic specificity between the biomarkers and tumors via the simultaneous determination of multiple tumor markers in electrochemical immunosensors. We also reported on the different types of immunosensors using $\mathrm{PB}$ or in-situ generation of $\mathrm{PB}$ via the electrochemical conversion of $\mathrm{Fe}_{3} \mathrm{O}_{4}$ as a transduction platform. Compared with a commercial ELISA, PBNPs-based immunosensors are a powerful competitor for tumor diagnosis. To improve the therapeutic efficacy of tumors, we introduced the synergistic effects of imaging-guided multimodal therapies mediated by pure PBNPs as well as combinations with chemotherapeutic or chemodynamic agents. Furthermore, we discussed the influence of various factors on the MRI image quality, including dopant effects, size control, testing temperature and choice of shape. The PAI effect was influenced by photothermal stability and photoacoustic signal-to-noise ratio. We described the application of integrated photosensitizers and fluorocarbons into PBNPs to obtain multiplex phototherapy and new imaging modalities such as FL, SERS, CT, and US imaging. Additionally, we discussed hydrophilic polymers, metal ions, biological ligands, and cell membranes used for surface modification to prolong the systemic circulation time, improve targeted accumulation at tumor sites, and control the release of drugs on triggering by $\mathrm{pH}$, redox, heat, or light stimuli. We summed up PBNPs-based photothermal treatment effect, which was determined by their chemical composition, size and irradiation time, and the power and photon excitation mode. PBNPs were extensively used as catalysts to improve the tumor treatment efficacy in PDT due to their ability of the generated $\mathrm{O}_{2}$ in $\mathrm{H}_{2} \mathrm{O}_{2}$ aqueous solution. Based on this review, the surveyed literature showed that PBNPs-based nanocomposites have excellent potential as an electron transfer mediator for sensors, 
as contrast agents for MRI and PAI, as drug carriers for anticarcinogen loading, as light absorbing agents for PTT and as a nanoenzymes for PDT to ensure high efficiency in tumor diagnosis and therapy. However, these studies are still in the early stages for the development of clinical PBNPs-based nanomedicines, and further progress is urgently required for practical clinical applications.

Author Contributions: Literature search, X.G., Q.W., and T.L. figures, X.G., T.L., and S.L.; study design, C.C. and X.H.; data collection, C.L., S.L., and T.L.; data analysis, Q.W. and C.L.; data interpretation, C.C. and X.H.; writing, X.G. and C.C. All authors have read and agreed to the published version of the manuscript.

Funding: This work was supported by National Natural Science Foundation of China (81901896); Tianjin University-Fuzhou University Independent Innovation Fund (TF2020-8); Scientific Research Foundation of Fuzhou University (GXRC-19025).

Conflicts of Interest: The authors declare no conflict of interest.

\section{References}

1. Song, Q.; Merajver, S.D.; Li, J.Z. Cancer classification in the genomic era: Five contemporary problems. Hum. Genom. 2015, 9, 27. [CrossRef] [PubMed]

2. Prablek, M.; Srinivasan, V.M.; Srivatsan, A.; Holdener, S.; Oneissi, M.; Heck, K.A.; Jalali, A.; Mandel, J.; Viswanathan, A.; Patel, A.J. Gastrointestinal stromal tumor with intracranial metastasis: Case presentation and systematic review of literature. BMC Cancer 2019, 19, 1119. [CrossRef] [PubMed]

3. Emon, B.; Bauer, J.; Jain, Y.; Jung, B.; Saif, T. Biophysics of Tumor Microenvironment and Cancer Metastasis-A Mini Review. Comput. Struct. Biotechnol. J. 2018, 16, 279-287. [CrossRef]

4. Ullah, M.F.; Aatif, M. The footprints of cancer development: Cancer biomarkers. Cancer Treat. Rev. 2009, 35, 193-200. [CrossRef] [PubMed]

5. Sethi, S.; Ali, S.; Philip, P.A.; Sarkar, F.H. Clinical advances in molecular biomarkers for cancer diagnosis and therapy. Int. J. Mol. Sci. 2013, 14, 14771-14784. [CrossRef]

6. Peterson, R.D.; Wilund, K.R.; Cunningham, B.T.; Andrade, J.E. Comparison of Methods Study between a Photonic Crystal Biosensor and Certified ELISA to Measure Biomarkers of Iron Deficiency in Chronic Kidney Disease Patients. Sensors 2017, 17, 2203. [CrossRef]

7. Wang, J. Electrochemical biosensors: Towards point-of-care cancer diagnostics. Biosens. Bioelectron. 2006, 21, 1887-1892. [CrossRef]

8. Wu, J.; Fu, Z.; Yan, F.; Ju, H. Biomedical and clinical applications of immunoassays and immunosensors for tumor markers. Trac. Trends Anal. Chem. 2007, 26, 679-688. [CrossRef]

9. Griffith, W.P. Cyanide complexes of the transition metals. Q. Rev. Chem. Soc. 1962, 16, 188. [CrossRef]

10. Adak, S.; Daemen, L.L.; Hartl, M.; Williams, D.; Summerhill, J.; Nakotte, H. Thermal expansion in 3d-metal Prussian Blue Analogs-A survey study. Solid State Chem. 2011, 184, 2854-2861. [CrossRef]

11. Neff, V.D. Electrochemical Oxidation and Reduction of Thin Films of Prussian Blue. J. Electrochem. Soc. 1978, 125, 886. [CrossRef]

12. Kong, B.; Tang, J.; Selomulya, C.; Li, W.; Wei, J.; Fang, Y.; Wang, Y.; Zheng, G.; Zhao, D. Oriented mesoporous nanopyramids as versatile plasmon-enhanced interfaces. J. Am. Chem Soc. 2014, 136, 6822-6825. [CrossRef] [PubMed]

13. Chu, Z.; Liu, Y.; Jin, W. Recent progress in Prussian blue films: Methods used to control regular nanostructures for electrochemical biosensing applications. Biosens. Bioelectron. 2017, 96, 17-25. [CrossRef]

14. Li, W.J.; Han, C.; Cheng, G.; Chou, S.L.; Liu, H.K.; Dou, S.X. Chemical Properties, Structural Properties, and Energy Storage Applications of Prussian Blue Analogues. Small 2019, 15, e1900470. [CrossRef] [PubMed]

15. Matos-Peralta, Y.; Antuch, M. Review-Prussian Blue and Its Analogs as Appealing Materials for Electrochemical Sensing and Biosensing. J. Electrochem. Soc. 2020, 167, 037510. [CrossRef]

16. Qin, Z.; Li, Y.; Gu, N. Progress in Applications of Prussian Blue Nanoparticles in Biomedicine. Adv. Health Mater. 2018, 7, e1800347. [CrossRef] [PubMed]

17. Duanghathaipornsuk, S.; Kanel, S.; Haushalter, E.F.; Ruetz, J.E.; Kim, D.S. Detection of Hydroxyl Radicals Using Cerium Oxide/Graphene Oxide Composite on Prussian Blue. Nanomaterials 2020, 10, 1136. [CrossRef]

18. Chen, J.; Wei, L.; Mahmood, A.; Pei, Z.; Zhou, Z.; Chen, X.; Chen, Y. Prussian blue, its analogues and their derived materials for electrochemical energy storage and conversion. Energy Storage Mater. 2020, 25, 585-612. [CrossRef] 
19. Jerez-Masaquiza, M.D.; Fernandez, L.; Gonzalez, G.; Montero-Jimenez, M.; Espinoza-Montero, P.J. Electrochemical Sensor Based on Prussian Blue Electrochemically Deposited at $\mathrm{ZrO}_{2}$ Doped Carbon Nanotubes Glassy Carbon Modified Electrode. Nanomaterials 2020, 10, 1328. [CrossRef]

20. Chen, J.; Yu, Q.; Fu, W.; Chen, X.; Zhang, Q.; Dong, S.; Chen, H.; Zhang, S. A Highly Sensitive Amperometric Glutamate Oxidase Microbiosensor Based on a Reduced Graphene Oxide/Prussian Blue Nanocube/Gold Nanoparticle Composite Film-Modified Pt Electrode. Sensors 2020, 20, 2924. [CrossRef]

21. Li, T.; Si, Z.; Hu, L.; Qi, H.; Yang, M. Prussian Blue-functionalized ceria nanoparticles as label for ultrasensitive detection of tumor necrosis factor- $\alpha$. Sens. Actuators B Chem. 2012, 171-172, 1060-1065. [CrossRef]

22. Zargar, B.; Hatamie, A. Prussian blue nanoparticles: A simple and fast optical sensor for colorimetric detection of hydralazine in pharmaceutical samples. Anal. Methods 2014, 6, 5951. [CrossRef]

23. Xu, W.; He, J.; Gao, L.; Zhang, J.; Hui, J.; Guo, Y.; Li, W.; Yu, C. A sensitive glucose biosensor based on the abundant immobilization of glucose oxidase on hollow $\mathrm{Pt}$ nanospheres assembled on graphene oxide-Prussian Blue-PTC-NH $\mathrm{N}_{2}$ nanocomposite film. J. Electroanal. Chem. 2015, 741, 8-13. [CrossRef]

24. Petropoulos, K.; Piermarini, S.; Bernardini, S.; Palleschi, G.; Moscone, D. Development of a disposable biosensor for lactate monitoring in saliva. Sens. Actuators B Chem. 2016, 237, 8-15. [CrossRef]

25. Zhu, D.; Zhu, W.; Xin, J.; Tan, L.; Wang, X.; Pang, H.; Ma, H. Prussian blue nanocubes with an open framework structure coated with polyoxometalates as a highly sensitive platform for ascorbic acid detection in drinks/human urine. New J. Chem. 2019, 43, 9420-9429. [CrossRef]

26. Wang, G.; Chen, L.; Zhu, Y.; He, X.; Xu, G.; Zhang, X. Prussian blue-Au nanocomposites actuated hemin/G-quadruplexes catalysis for amplified detection of DNA, $\mathrm{Hg}^{2+}$ and adenosine triphosphate. Analyst 2014, 139, 5297-5303. [CrossRef]

27. Namgung, H.; Gwon, Y.J.; Kim, J.; Jang, G.; Pepper, S.E.; Ogden, M.D.; Whittle, K.R.; Harwood, L.M.; Lee, T.S. Synthesis of Prussian blue-embedded porous polymer for detection and removal of Cs ions. Polymer 2018, 158, 320-326. [CrossRef]

28. Yamada, M.; Ohnishi, N.; Watanabe, M.; Hino, Y. Prussian blue nanoparticles protected by the water-soluble pi-conjugated polymer PEDOT-S: Synthesis and multiple-color $\mathrm{pH}$-sensing with a redox reaction. Chem. Commun. 2009, 7203-7205. [CrossRef]

29. Jo, G.; Lee, B.Y.; Kim, E.J.; Park, M.H.; Hyun, H. Indocyanine Green and Methyl-beta-Cyclodextrin Complex for Enhanced Photothermal Cancer Therapy. Biomedicines 2020, 8, 476. [CrossRef]

30. Wang, R.; Yang, H.; Fu, R.; Su, Y.; Lin, X.; Jin, X.; Du, W.; Shan, X.; Huang, G. Biomimetic Upconversion Nanoparticles and Gold Nanoparticles for Novel Simultaneous Dual-Modal Imaging-Guided Photothermal Therapy of Cancer. Cancers 2020, 12, 3136. [CrossRef]

31. Long, J.; Guari, Y.; Guerin, C.; Larionova, J. Prussian blue type nanoparticles for biomedical applications. Dalton Trans. 2016, 45, 17581-17587. [CrossRef] [PubMed]

32. Shokouhimehr, M.; Soehnlen, E.S.; Hao, J.; Griswold, M.; Flask, C.; Fan, X.; Basilion, J.P.; Basu, S.; Huang, S.D. Dual purpose Prussian blue nanoparticles for cellular imaging and drug delivery: A new generation of $\mathrm{T}_{1}$-weighted MRI contrast and small molecule delivery agents. J. Mater. Chem. 2010, 20, 5251. [CrossRef]

33. Li, Z.; Zeng, Y.; Zhang, D.; Wu, M.; Wu, L.; Huang, A.; Yang, H.; Liu, X.; Liu, J. Glypican-3 antibody functionalized Prussian blue nanoparticles for targeted MR imaging and photothermal therapy of hepatocellular carcinoma. J. Mater. Chem. B 2014, 2, 3686-3696. [CrossRef] [PubMed]

34. Perera, V.S.; Chen, G.; Cai, Q.; Huang, S.D. Nanoparticles of gadolinium-incorporated Prussian blue with PEG coating as an effective oral MRI contrast agent for gastrointestinal tract imaging. Analyst 2016, 141, 2016-2022. [CrossRef]

35. Paul, G.; Prado, Y.; Dia, N.; Riviere, E.; Laurent, S.; Roch, M.; Elst, L.V.; Muller, R.N.; Sancey, L.; Perriat, P.; et al. $\mathrm{Mn}^{\mathrm{II}}$-containing coordination nanoparticles as highly efficient $\mathrm{T}_{1}$ contrast agents for magnetic resonance imaging. Chem. Commun. 2014, 50, 6740-6743. [CrossRef]

36. Fetiveau, L.; Paul, G.; Nicolas-Boluda, A.; Volatron, J.; George, R.; Laurent, S.; Muller, R.; Sancey, L.; Mejanelle, P.; Gloter, A.; et al. Tailored ultra-small Prussian blue-based nanoparticles for MRI imaging and combined photothermal/photoacoustic theranostics. Chem. Commun. 2019, 55, 14844-14847. [CrossRef]

37. Ali, L.M.A.; Mathlouthi, E.; Kajdan, M.; Daurat, M.; Long, J.; Sidi-Boulenouar, R.; Cardoso, M.; Goze-Bac, C.; Amdouni, N.; Guari, Y.; et al. Multifunctional manganese-doped Prussian blue nanoparticles for two-photon photothermal therapy and magnetic resonance imaging. Photodiagnosis Photodyn 2018, 22, 65-69. [CrossRef] 
38. Cai, X.; Gao, W.; Ma, M.; Wu, M.; Zhang, L.; Zheng, Y.; Chen, H.; Shi, J. A Prussian Blue-Based Core-Shell Hollow-Structured Mesoporous Nanoparticle as a Smart Theranostic Agent with Ultrahigh pH-Responsive Longitudinal Relaxivity. Adv. Mater. 2015, 27, 6382-6389. [CrossRef]

39. Cheng, M.; Peng, W.; Hua, P.; Chen, Z.; Sheng, J.; Yang, J.; Wu, Y. In situ formation of pH-responsive Prussian blue for photoacoustic imaging and photothermal therapy of cancer. RSC Adv. 2017, 7, 18270-18276. [CrossRef]

40. Dumani, D.S.; Cook, J.R.; Kubelick, K.P.; Luci, J.J.; Emelianov, S.Y. Photomagnetic Prussian blue nanocubes: Synthesis, characterization, and biomedical applications. Nanomedicine 2020, 24, 102138. [CrossRef]

41. Xu, Y.; Zhang, Y.; Cai, X.; Gao, W.; Tang, X.; Chen, Y.; Chen, J.; Chen, L.; Tian, Q.; Yang, S.; et al. Large-scale synthesis of monodisperse Prussian blue nanoparticles for cancer theranostics via an "in situ modification" strategy. Int. J. Nanomed. 2019, 14, 271-288. [CrossRef] [PubMed]

42. Kubelick, K.P.; Emelianov, S.Y. Prussian blue nanocubes as a multimodal contrast agent for image-guided stem cell therapy of the spinal cord. Photoacoustics 2020, 18, 100166. [CrossRef] [PubMed]

43. Li, W.; Chen, R.; Lv, J.; Wang, H.; Liu, Y.; Peng, Y.; Qian, Z.; Fu, G.; Nie, L. In Vivo Photoacoustic Imaging of Brain Injury and Rehabilitation by High-Efficient Near-Infrared Dye Labeled Mesenchymal Stem Cells with Enhanced Brain Barrier Permeability. Adv. Sci. 2018, 5, 1700277. [CrossRef]

44. Steinberg, I.; Huland, D.M.; Vermesh, O.; Frostig, H.E.; Tummers, W.S.; Gambhir, S.S. Photoacoustic clinical imaging. Photoacoustics 2019, 14, 77-98. [CrossRef]

45. Wang, D.; Zhou, J.; Chen, R.; Shi, R.; Zhao, G.; Xia, G.; Li, R.; Liu, Z.; Tian, J.; Wang, H.; et al. Controllable synthesis of dual-MOFs nanostructures for $\mathrm{pH}$-responsive artemisinin delivery, magnetic resonance and optical dual-model imaging-guided chemo/photothermal combinational cancer therapy. Biomaterials 2016, 100, 27-40. [CrossRef]

46. Liu, B.; Wang, W.; Fan, J.; Long, Y.; Xiao, F.; Daniyal, M.; Tong, C.; Xie, Q.; Jian, Y.; Li, B.; et al. RBC membrane camouflaged prussian blue nanoparticles for gamabutolin loading and combined chemo/photothermal therapy of breast cancer. Biomaterials 2019, 217, 119301. [CrossRef]

47. Xiao, F.; Fan, J.; Tong, C.; Xiao, C.; Wang, Z.; Liu, B.; Daniyal, M.; Wang, W. An erythrocyte membrane coated mimetic nano-platform for chemo-phototherapy and multimodal imaging. RSC Adv. 2019, 9, 27911-27926. [CrossRef]

48. Gautam, M.; Poudel, K.; Yong, C.S.; Kim, J.O. Prussian blue nanoparticles: Synthesis, surface modification, and application in cancer treatment. Int. J. Pharm 2018, 549, 31-49. [CrossRef]

49. Busquets, M.A.; Novella-Xicoy, A.; Guzman, V.; Estelrich, J. Facile Synthesis of Novel Prussian Blue-Lipid Nanocomplexes. Molecules 2019, 24, 4137. [CrossRef]

50. Zhang, H.; Pei, Y.; Zhang, X.; Zhu, L.; Hou, L.; Chang, J.; Zhang, Z. Engineering of an intelligent cascade nanoreactor for sequential improvement of microenvironment and enhanced tumor phototherapy. Appl. Mater. Today 2020, 18, 100494. [CrossRef]

51. Chen, Y.; Wu, L.; Wang, Q.; Wu, M.; Xu, B.; Liu, X.; Liu, J. Toxicological evaluation of Prussian blue nanoparticles after short exposure of mice. Hum. Exp. Toxicol. 2016, 35, 1123-1132. [CrossRef]

52. Patra, C.R. Prussian blue nanoparticles and their analogues for application to cancer theranostics. Nanomedicine 2016, 11, 569-572. [CrossRef]

53. Khanmohammadi, A.; Aghaie, A.; Vahedi, E.; Qazvini, A.; Ghanei, M.; Afkhami, A.; Hajian, A.; Bagheri, H. Electrochemical biosensors for the detection of lung cancer biomarkers: A review. Talanta 2020, 206, 120251. [CrossRef]

54. Filik, H.; Avan, A.A. Nanostructures for nonlabeled and labeled electrochemical immunosensors: Simultaneous electrochemical detection of cancer markers: A review. Talanta 2019, 205, 120153. [CrossRef]

55. Ricci, F.; Palleschi, G. Sensor and biosensor preparation, optimisation and applications of Prussian Blue modified electrodes. Biosens. Bioelectron. 2005, 21, 389-407. [CrossRef]

56. Itaya, K. Electrochemistry of Prussian Blue Modified Electrodes: An Electrochemical Preparation Method. J. Electrochem. Soc. 1982, 129, 1498-1500. [CrossRef]

57. Itaya, K.; Ataka, T.; Toshima, S. Spectroelectrochemistry and electrochemical preparation method of Prussian blue modified electrodes. J. Am. Chem. Soc. 1982, 104, 4767-4772. [CrossRef]

58. Itaya, K.; Shoji, N.; Uchida, I. Catalysis of the reduction of molecular oxygen to water at Prussian blue modified electrodes. J. Am. Chem. Soc. 1984, 106, 3423-3429. [CrossRef] 
59. Karyakin, A.A.; Gitelmacher, O.V.; Karyakina, E.E. A High-Sensitive Glucose Amperometric Biosensor Based on Prussian Blue Modified Electrodes. Anal. Lett. 1994, 27, 2861-2869. [CrossRef]

60. Karyakin, A.A. Advances of Prussian blue and its analogues in (bio)sensors. Curr. Opin. Electrochem. 2017, 5, 92-98. [CrossRef]

61. Dai, Y.; Cai, Y.; Zhao, Y.; Wu, D.; Liu, B.; Li, R.; Yang, M.; Wei, Q.; Du, B.; Li, H. Sensitive sandwich electrochemical immunosensor for alpha fetoprotein based on prussian blue modified hydroxyapatite. Biosens. Bioelectron. 2011, 28, 112-116. [CrossRef] [PubMed]

62. Wu, Y.; Wang, Y.; Wang, X.; Wang, C.; Li, C.; Wang, Z. Electrochemical Sensing of alpha-Fetoprotein Based on Molecularly Imprinted Polymerized Ionic Liquid Film on a Gold Nanoparticle Modified Electrode Surface. Sensors 2019, 19, 3218. [CrossRef] [PubMed]

63. Filik, H.; Avan, A.A. Electrochemical immunosensors for the detection of cytokine tumor necrosis factor alpha: A review. Talanta 2020, 211, 120758. [CrossRef] [PubMed]

64. Anik, Ü.; Timur, S. Towards the electrochemical diagnosis of cancer: Nanomaterial-based immunosensors and cytosensors. RSC Adv. 2016, 6, 111831-111841. [CrossRef]

65. Bentzen, S.M.; Buffa, F.M.; Wilson, G.D. Multiple biomarker tissue microarrays: Bioinformatics and practical approaches. Cancer Metastasis Rev. 2008, 27, 481-494. [CrossRef]

66. Lai, G.; Yan, F.; Ju, H. Dual Signal Amplification of Glucose Oxidase-Functionalized Nanocomposites as a Trace Label for Ultrasensitive Simultaneous Multiplexed Electrochemical Detection of Tumor Markers. Anal. Chem. 2009, 81, 9730-9736. [CrossRef]

67. Garg, B.; Bisht, T.; Ling, Y.C. Graphene-Based Nanomaterials as Efficient Peroxidase Mimetic Catalysts for Biosensing Applications: An Overview. Molecules 2015, 20, 14155-14190. [CrossRef]

68. Lai, G.; Wang, L.; Wu, J.; Ju, H.; Yan, F. Electrochemical stripping analysis of nanogold label-induced silver deposition for ultrasensitive multiplexed detection of tumor markers. Anal. Chim. Acta 2012, 721, 1-6. [CrossRef]

69. Chen, X.; Jia, X.; Han, J.; Ma, J.; Ma, Z. Electrochemical immunosensor for simultaneous detection of multiplex cancer biomarkers based on graphene nanocomposites. Biosens. Bioelectron. 2013, 50, 356-361. [CrossRef]

70. Li, W.; Fan, G.C.; Fan, X.; Zhang, R.; Wang, L.; Wang, W.; Luo, X. Low fouling and ultrasensitive electrochemical immunosensors with dual assay methods based on $\mathrm{Fe}_{3} \mathrm{O}_{4}$ magnetic nanoparticles. J. Mater. Chem. B 2019, 7, 5842-5847. [CrossRef]

71. Dong, X.; Zhao, G.; Liu, L.; Li, X.; Wei, Q.; Cao, W. Ultrasensitive competitive method-based electrochemiluminescence immunosensor for diethylstilbestrol detection based on $\mathrm{Ru}(\mathrm{bpy})_{3}{ }^{2+}$ as luminophor encapsulated in metal-organic frameworks UiO-67. Biosens. Bioelectron. 2018, 110, 201-206. [CrossRef]

72. Kokkinos, C.; Angelopoulou, M.; Economou, A.; Prodromidis, M.; Florou, A.; Haasnoot, W.; Petrou, P.; Kakabakos, S. Lab-on-a-Membrane Foldable Devices for Duplex Drop-Volume Electrochemical Biosensing Using Quantum Dot Tags. Anal. Chem. 2016, 88, 6897-6904. [CrossRef] [PubMed]

73. Yin, S.; Ma, Z. Self-sacrificial label assisted electroactivity conversion of sensing interface for ultrasensitive electrochemical immunosensor. Biosens. Bioelectron. 2019, 140, 111355. [CrossRef] [PubMed]

74. Lee, N.; Hyeon, T. Designed synthesis of uniformly sized iron oxide nanoparticles for efficient magnetic resonance imaging contrast agents. Chem. Soc. Rev. 2012, 41, 2575-2589. [CrossRef]

75. Wang, L.; Huang, J.; Chen, H.; Wu, H.; Xu, Y.; Li, Y.; Yi, H.; Wang, Y.; Yang, L.; Mao, H. Exerting Enhanced Permeability and Retention Effect Driven Delivery by Ultrafine Iron Oxide Nanoparticles with $\mathrm{T}_{1}-\mathrm{T}_{2}$ Switchable Magnetic Resonance Imaging Contrast. ACS Nano 2017, 11, 4582-4592. [CrossRef]

76. Ni, D.; Bu, W.; Ehlerding, E.B.; Cai, W.; Shi, J. Engineering of inorganic nanoparticles as magnetic resonance imaging contrast agents. Chem. Soc. Rev. 2017, 46, 7438-7468. [CrossRef]

77. Zhang, Y.; Yu, J.; Kahkoska, A.R.; Gu, Z. Photoacoustic Drug Delivery. Sensors 2017, 17, 1400. [CrossRef]

78. Liu, Y.; Li, D.; Yuan, Z. Photoacoustic Tomography Imaging of the Adult Zebrafish by Using Unfocused and Focused High-Frequency Ultrasound Transducers. Appl. Sci. 2016, 6, 392. [CrossRef]

79. Kratkiewicz, K.; Manwar, R.; Rajabi-Estarabadi, A.; Fakhoury, J.; Meiliute, J.; Daveluy, S.; Mehregan, D.; Avanaki, K.M. Photoacoustic/Ultrasound/Optical Coherence Tomography Evaluation of Melanoma Lesion and Healthy Skin in a Swine Model. Sensors 2019, 19, 2815. [CrossRef]

80. Wang, H.; Ma, Y.; Yang, H.; Jiang, H.; Ding, Y.; Xie, H. MEMS Ultrasound Transducers for Endoscopic Photoacoustic Imaging Applications. Micromachines 2020, 11, 928. [CrossRef] 
81. Tsang, V.T.C.; Li, X.; Wong, T.T.W. A Review of Endogenous and Exogenous Contrast Agents Used in Photoacoustic Tomography with Different Sensing Configurations. Sensors 2020, 20, 5595 . [CrossRef] [PubMed]

82. Liang, X.; Deng, Z.; Jing, L.; Li, X.; Dai, Z.; Li, C.; Huang, M. Prussian blue nanoparticles operate as a contrast agent for enhanced photoacoustic imaging. Chem. Commun. 2013, 49, 11029-11031. [CrossRef] [PubMed]

83. Zheng, T.; Zhou, T.; Feng, X.; Shen, J.; Zhang, M.; Sun, Y. Enhanced Plasmon-Induced Resonance Energy Transfer (PIRET)-Mediated Photothermal and Photodynamic Therapy Guided by Photoacoustic and Magnetic Resonance Imaging. ACS Appl. Mater. Interfaces 2019, 11, 31615-31626. [CrossRef] [PubMed]

84. Zhou, J.; Tian, G.; Zeng, L.; Song, X.; Bian, X.-W. Nanoscaled Metal-Organic Frameworks for Biosensing, Imaging, and Cancer Therapy. Adv. Health Mater. 2018, 7, 1800022. [CrossRef]

85. Karimi, M.; Ghasemi, A.; Sahandi Zangabad, P.; Rahighi, R.; Moosavi Basri, S.M.; Mirshekari, H.; Amiri, M.; Shafaei Pishabad, Z.; Aslani, A.; Bozorgomid, M.; et al. Smart micro/nanoparticles in stimulus-responsive drug/gene delivery systems. Chem. Soc. Rev. 2016, 45, 1457-1501. [CrossRef]

86. Jia, Q.; Li, Z.; Guo, C.; Huang, X.; Kang, M.; Song, Y.; He, L.; Zhou, N.; Wang, M.; Zhang, Z.; et al. PEGMA-modified bimetallic NiCo Prussian blue analogue doped with $\mathrm{Tb}^{\mathrm{III}}$ ions: Efficiently $\mathrm{pH}$-responsive and controlled release system for anticancer drug. Chem. Eng. J. 2020, 389, 124468. [CrossRef]

87. Li, Y.; Dang, J.; Liang, Q.; Yin, L. Thermal-Responsive Carbon Monoxide (CO) Delivery Expedites Metabolic Exhaustion of Cancer Cells toward Reversal of Chemotherapy Resistance. ACS Cent. Sci 2019, 5, 1044-1058. [CrossRef]

88. Chen, J.; Ning, C.; Zhou, Z.; Yu, P.; Zhu, Y.; Tan, G.; Mao, C. Nanomaterials as photothermal therapeutic agents. Prog. Mater. Sci. 2019, 99, 1-26. [CrossRef]

89. Chen, X.; Wu, G.; Tang, J.; Zhou, L.; Wei, S. Ytterbium—Doped Prussian blue: Fabrication, photothermal performance and antibacterial activity. Inorganic Chem. Commun. 2020, 114, 107821. [CrossRef]

90. Fu, G.; Liu, W.; Feng, S.; Yue, X. Prussian blue nanoparticles operate as a new generation of photothermal ablation agents for cancer therapy. Chem. Commun. 2012, 48, 11567-11569. [CrossRef]

91. Yu, Z.; Hu, W.; Zhao, H.; Miao, X.; Guan, Y.; Cai, W.; Zeng, Z.; Fan, Q.; Tan, T.T.Y. Generating New Cross-Relaxation Pathways by Coating Prussian Blue on NaNdF4 To Fabricate Enhanced Photothermal Agents. Angew. Chem. 2019, 58, 8536-8540. [CrossRef] [PubMed]

92. Roper, D.K.; Ahn, W.; Hoepfner, M. Microscale Heat Transfer Transduced by Surface Plasmon Resonant Gold Nanoparticles. J. Phys. Chem. C Nanomater. Interfaces 2007, 111, 3636-3641. [CrossRef] [PubMed]

93. Wang, X.; Li, H.; Li, F.; Han, X.; Chen, G. Prussian blue-coated lanthanide-doped core/shell/shell nanocrystals for NIR-II image-guided photothermal therapy. Nanoscale 2019, 11, 22079-22088. [CrossRef] [PubMed]

94. Shou, P.; Yu, Z.; Wu, Y.; Feng, Q.; Zhou, B.; Xing, J.; Liu, C.; Tu, J.; Akakuru, O.U.; Ye, Z.; et al. Zn ${ }^{2+}$ Doped Ultrasmall Prussian Blue Nanotheranostic Agent for Breast Cancer Photothermal Therapy under MR Imaging Guidance. Adv. Health Mater. 2020, 9, e1900948. [CrossRef] [PubMed]

95. Ali, L.M.A.; Mathlouthi, E.; Cahu, M.; Sene, S.; Daurat, M.; Long, J.; Guari, Y.; Salles, F.; Chopineau, J.; Devoisselle, J.-M.; et al. Synergic effect of doxorubicin release and two-photon irradiation of $\mathrm{Mn}^{2+}$-doped Prussian blue nanoparticles on cancer therapy. RSC Adv. 2020, 10, 2646-2649. [CrossRef]

96. Yanovsky, R.L.; Bartenstein, D.W.; Rogers, G.S.; Isakoff, S.J.; Chen, S.T. Photodynamic therapy for solid tumors: A review of the literature. Photodermatol. Photoimmunol. Photomed. 2019, 35, 295-303. [CrossRef]

97. Chen, H.; He, W.; Guo, Z. An $\mathrm{H}_{2} \mathrm{O}_{2}$-responsive nanocarrier for dual-release of platinum anticancer drugs and $\mathrm{O}_{2}$ : Controlled release and enhanced cytotoxicity against cisplatin resistant cancer cells. Chem. Commun. 2014, 50, 9714-9717. [CrossRef]

98. Li, H.; Zhang, W.; Ding, L.; Li, X.W.; Wu, Y.; Tang, J.H. Prussian blue-modified ferritin nanoparticles for effective tumor chemo-photothermal combination therapy via enhancing reactive oxygen species production. J. Biomater. Appl. 2019, 33, 1202-1213. [CrossRef]

99. Yang, F.; Hu, S.; Zhang, Y.; Cai, X.; Huang, Y.; Wang, F.; Wen, S.; Teng, G.; Gu, N. A hydrogen peroxide-responsive $\mathrm{O}_{2}$ nanogenerator for ultrasound and magnetic-resonance dual modality imaging. Adv. Mater. 2012, 24, 5205-5211. [CrossRef]

100. Wang, D.; Shi, R.; Zhou, J.; Shi, S.; Wu, H.; Xu, P.; Wang, H.; Xia, G.; Barnhart, T.E.; Cai, W.; et al. Photo-Enhanced Singlet Oxygen Generation of Prussian Blue-Based Nanocatalyst for Augmented Photodynamic Therapy. iScience 2018, 9, 14-26. [CrossRef] 
101. Odda, A.H.; Xu, Y.; Lin, J.; Wang, G.; Ullah, N.; Zeb, A.; Liang, K.; Wen, L.P.; Xu, A.W. Plasmonic $\mathrm{MoO}_{3-\mathrm{x}}$ nanoparticles incorporated in Prussian blue frameworks exhibit highly efficient dual photothermal/photodynamic therapy. J. Mater. Chem B 2019, 7, 2032-2042. [CrossRef] [PubMed]

102. Sun, L.; Li, Q.; Hou, M.; Gao, Y.; Yang, R.; Zhang, L.; Xu, Z.; Kang, Y.; Xue, P. Light-activatable Chlorin e6 (Ce6)-imbedded erythrocyte membrane vesicles camouflaged Prussian blue nanoparticles for synergistic photothermal and photodynamic therapies of cancer. Biomater. Sci. 2018, 6, 2881-2895. [CrossRef] [PubMed]

103. Yang, Z.L.; Tian, W.; Wang, Q.; Zhao, Y.; Zhang, Y.L.; Tian, Y.; Tang, Y.X.; Wang, S.J.; Liu, Y.; Ni, Q.Q.; et al. Oxygen-Evolving Mesoporous Organosilica Coated Prussian Blue Nanoplatform for Highly Efficient Photodynamic Therapy of Tumors. Adv. Sci. 2018, 5, 1700847. [CrossRef] [PubMed]

104. Cai, X.; Gao, W.; Zhang, L.; Ma, M.; Liu, T.; Du, W.; Zheng, Y.; Chen, H.; Shi, J. Enabling Prussian Blue with Tunable Localized Surface Plasmon Resonances: Simultaneously Enhanced Dual-Mode Imaging and Tumor Photothermal Therapy. ACS Nano 2016, 10, 11115-11126. [CrossRef]

105. Peng, J.; Dong, M.; Ran, B.; Li, W.; Hao, Y.; Yang, Q.; Tan, L.; Shi, K.; Qian, Z. “One-for-All”-Type, Biodegradable Prussian Blue/Manganese Dioxide Hybrid Nanocrystal for Trimodal Imaging-Guided Photothermal Therapy and Oxygen Regulation of Breast Cancer. ACS Appl. Mater. Interfaces 2017, 9, 13875-13886. [CrossRef]

106. Jing, L.; Liang, X.; Deng, Z.; Feng, S.; Li, X.; Huang, M.; Li, C.; Dai, Z. Prussian blue coated gold nanoparticles for simultaneous photoacoustic/CT bimodal imaging and photothermal ablation of cancer. Biomaterials 2014, 35, 5814-5821. [CrossRef]

107. Zhu, W.; Gao, M.Y.; Zhu, Q.; Chi, B.; Zeng, L.W.; Hu, J.M.; Shen, A.G. Monodispersed plasmonic Prussian blue nanoparticles for zero-background SERS/MRI-guided phototherapy. Nanoscale 2020, 12, 3292-3301. [CrossRef]

108. Peng, X.; Wang, R.; Wang, T.; Yang, W.; Wang, H.; Gu, W.; Ye, L. Carbon Dots/Prussian Blue Satellite/Core Nanocomposites for Optical Imaging and Photothermal Therapy. ACS Appl. Mater. Interfaces 2018, 10, 1084-1092. [CrossRef]

109. Sahu, A.; Lee, J.H.; Lee, H.G.; Jeong, Y.Y.; Tae, G. Prussian blue/serum albumin/indocyanine green as a multifunctional nanotheranostic agent for bimodal imaging guided laser mediated combinatorial phototherapy. J. Control. Release 2016, 236, 90-99. [CrossRef]

110. Zhang, N.; Cai, X.; Gao, W.; Wang, R.; Xu, C.; Yao, Y.; Hao, L.; Sheng, D.; Chen, H.; Wang, Z.; et al. A Multifunctional Theranostic Nanoagent for Dual-Mode Image-Guided HIFU/Chemo-Synergistic Cancer Therapy. Theranostics 2016, 6, 404-417. [CrossRef]

111. Zhang, M.; Sheng, B.; Ashley, J.; Zheng, T.; Wang, W.; Zhang, Q.; Zhang, J.; Zhou, N.; Shen, J.; Sun, Y. Manganese ion chelated FeOCl@PB@PDA@BPQDs nanocomposites as a tumor microenvironment-mediated nanoplatform for enhanced tumor imaging and therapy. Sens. Actuators B Chem. 2020, 307, 127491. [CrossRef]

112. Santha Moorthy, M.; Hoang, G.; Subramanian, B.; Bui, N.Q.; Panchanathan, M.; Mondal, S.; Thi Tuong, V.P.; Kim, H.; Oh, J. Prussian blue decorated mesoporous silica hybrid nanocarriers for photoacoustic imaging-guided synergistic chemo-photothermal combination therapy. J. Mater. Chem. B 2018, 6, 5220-5233. [CrossRef] [PubMed]

113. Fu, G.; Liu, W.; Li, Y.; Jin, Y.; Jiang, L.; Liang, X.; Feng, S.; Dai, Z. Magnetic Prussian blue nanoparticles for targeted photothermal therapy under magnetic resonance imaging guidance. Bioconjugate Chem. 2014, 25, 1655-1663. [CrossRef] [PubMed]

114. Zhang, H.F.; Maslov, K.; Stoica, G.; Wang, L.V. Functional photoacoustic microscopy for high-resolution and noninvasive in vivo imaging. Nat. Biotechnol. 2006, 24, 848-851. [CrossRef]

115. Kim, C.; Favazza, C.; Wang, L.V. In vivo photoacoustic tomography of chemicals: High-resolution functional and molecular optical imaging at new depths. Chem. Rev. 2010, 110, 2756-2782. [CrossRef]

116. Terreno, E.; Castelli, D.D.; Viale, A.; Aime, S. Challenges for Molecular Magnetic Resonance Imaging. Chem. Rev. 2010, 110, 3019-3042. [CrossRef]

117. Lee, N.; Yoo, D.; Ling, D.; Cho, M.H.; Hyeon, T.; Cheon, J. Iron Oxide Based Nanoparticles for Multimodal Imaging and Magnetoresponsive Therapy. Chem. Rev. 2015, 115, 10637-10689. [CrossRef]

118. Jia, X.; Cai, X.; Chen, Y.; Wang, S.; Xu, H.; Zhang, K.; Ma, M.; Wu, H.; Shi, J.; Chen, H. Perfluoropentane-encapsulated hollow mesoporous prussian blue nanocubes for activated ultrasound imaging and photothermal therapy of cancer. ACS Appl. Mater. Interfaces 2015, 7, 4579-4588. [CrossRef] 
119. Faust, O.; Acharya, U.R.; Meiburger, K.M.; Molinari, F.; Koh, J.E.W.; Yeong, C.H.; Kongmebhol, P.; Ng, K.H. Comparative assessment of texture features for the identification of cancer in ultrasound images: A review. Biocybern. Biomed. Eng. 2018, 38, 275-296. [CrossRef]

120. Wu, W.J.; Moon, W.K. Ultrasound breast tumor image computer-aided diagnosis with texture and morphological features. Acad. Radiol. 2008, 15, 873-880. [CrossRef]

Publisher's Note: MDPI stays neutral with regard to jurisdictional claims in published maps and institutional affiliations.

(C) 2020 by the authors. Licensee MDPI, Basel, Switzerland. This article is an open access article distributed under the terms and conditions of the Creative Commons Attribution (CC BY) license (http://creativecommons.org/licenses/by/4.0/). 